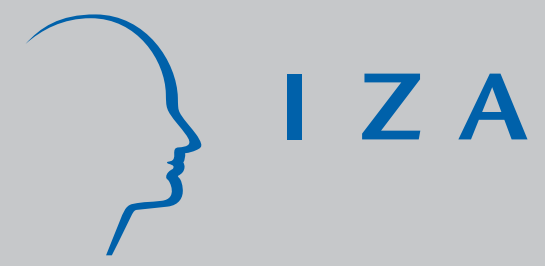

IZA DP No. 5708

The Aftermath of Reunification: Sectoral Transition, Gender, and Rising Wage Inequality in East Germany

Karsten Kohn

Dirk Antonczyk

May 2011 


\title{
The Aftermath of Reunification: Sectoral Transition, Gender, and Rising Wage Inequality in East Germany
}

\author{
Karsten Kohn \\ KfW Bankengruppe \\ and IZA \\ Dirk Antonczyk \\ Albert-Ludwigs-University Freiburg \\ and IZA \\ Discussion Paper No. 5708 \\ May 2011 \\ IZA \\ P.O. Box 7240 \\ 53072 Bonn \\ Germany \\ Phone: +49-228-3894-0 \\ Fax: +49-228-3894-180 \\ E-mail: iza@iza.org
}

Any opinions expressed here are those of the author(s) and not those of IZA. Research published in this series may include views on policy, but the institute itself takes no institutional policy positions.

The Institute for the Study of Labor (IZA) in Bonn is a local and virtual international research center and a place of communication between science, politics and business. IZA is an independent nonprofit organization supported by Deutsche Post Foundation. The center is associated with the University of Bonn and offers a stimulating research environment through its international network, workshops and conferences, data service, project support, research visits and doctoral program. IZA engages in (i) original and internationally competitive research in all fields of labor economics, (ii) development of policy concepts, and (iii) dissemination of research results and concepts to the interested public.

IZA Discussion Papers often represent preliminary work and are circulated to encourage discussion. Citation of such a paper should account for its provisional character. A revised version may be available directly from the author. 


\section{ABSTRACT}

\section{The Aftermath of Reunification: Sectoral Transition, Gender, and Rising Wage Inequality in East Germany ${ }^{*}$}

Using a large administrative data set, this paper studies the evolution of the East German wage structure throughout the transition period 1992-2001. Wage dispersion has generally been rising. The increase occurred predominantly in the lower part of the wage distribution for women and in the upper part for men. Sectoral transition affected women to a much larger extent than men. A sequential decomposition analysis using quantile regressions reveals that changes in industry-specific remuneration schemes contributed strongly to the rise in wage inequality in the lower part of the distribution for female workers. On the other hand, interindustry trends away from the manufacturing sector towards service sectors contribute to the smaller increase of inequality in the upper part of the distribution, while causing wage dispersion in the lower part of the distribution to decline. Changes in the industry composition alone would have led to a polarization of wages for female workers. For men, changes in individual characteristics and a general time trend contribute the largest part to the increasing wage dispersion. These gender differences result from employment segregation across industries right after German reunification, and a particularly strong concentration of females in the public sector.

JEL Classification: J31, C21

Keywords: wage distribution, transition, gender, decomposition, quantile regression, polarization, East Germany

Corresponding author:

Karsten Kohn

KfW Bankengruppe

Economics Department

Palmengartenstr. 5-9

60325 Frankfurt am Main

Germany

E-mail: karsten.kohn@kfw.de

\footnotetext{
* Opinions expressed in this article reflect the personal views of the authors and not necessarily those of KfW. We thank Melanie Arntz, Martin Biewen, Davide Cantoni, Bernd Fitzenberger, and Astrid Kunze and participants of conferences and workshops in Freiburg, Nuremberg, Mannheim, and Vienna for helpful discussions and constructive comments. The responsibility for all errors is, of course, ours.
} 


\section{Introduction}

Conventional wisdom suggests that the structure of wages under socialist regimes is more compressed than it is in market economies. Concerning the former communist economies in Eastern Europe, two more issues stand out: First, participation rates of female workers in many Eastern European countries were very high compared to Western standards. Second, occupational choices in many of these countries were fairly limited and there existed a clear pattern of occupational segregation by gender, which was at least partly based upon the communist ideology (Oglobin, 1999). After the fall of the iron curtain, market forces were free to act in many Eastern European countries which had formerly been in the sphere of influence of the Soviet Union.

This study analyzes the evolution of wage dispersion in East ${ }^{1}$ Germany during the period 1992-2001, i.e., the first decade after German reunification. ${ }^{2}$ The particular focus lies on differences in the evolution of wage dispersion across gender. Wage inequality in East Germany was low right after the German reunification, but then grew strongly during the 1990s, reaching the level of West $^{3}$ Germany. Applying a sequential decomposition approach based on quantile regressions, we analyze the importance of changes in individual characteristics and inter-industry shifts (the characteristics effects) for changes in wage inequality for both male and female workers, as well as the impact of changing endowments to these characteristics (the coefficients effects). This decomposition approach is complemented by comprehensive descriptive statistics helping us to identify possible causes for the observed changes in the wage structure.

The paper contributes to the literature by addressing the following questions: How do gender differences evolve across the wage distribution after transition from a communist to a market-oriented regime? What is the impact of changes in individual characteristics - which may be driven by migration, changes in labor force participation, and skillupgrading - on the evolution of the wage structure? How much of the observed increase in wage inequality is explained by inter-industry shifts, i.e., the restructuring of the economy? What is the impact of changes in remuneration schemes across industries, which may be influenced by, e.g., unions, and what is the impact of the evolution of prices for human capital, on wage dispersion?

In order to answer these questions, we decompose changes in overall wage inequality among male and female workers in East Germany between 1992 and 2001. The large sample size of the employed IABS data, a $2 \%$ random sample of all social security records in Germany, allows the application of quantile regression techniques. Quantile regressions are more flexible than the least squares estimations employed by most existing studies.

\footnotetext{
${ }^{1}$ German States (Länder) formerly belonging to the German Democratic Republic (GDR).

${ }^{2}$ After 45 years of division, Germany was reunited on October 3rd, 1990.

${ }^{3}$ States which had belonged to the Federal Republic of Germany (FRG) before reunification.
} 
Drawing on the sequential decomposition introduced by Antonczyk et al. (2010b), which itself builds upon techniques suggested by Machado and Mata (2005) and DiNardo et al. (1996), we pin down the effects of changes in individual characteristics and changes in the industry composition as well as their corresponding coefficients on changes of the wage structure. This decomposition approach is well-suited to depict heterogeneous characteristics and coefficients effects across the wage distribution. As the observed joint sample distribution of the covariates is explicitly taken into account, the decomposition effects are identified as differences between clearly defined counterfactual wage distributions. In addition, we provide comprehensive statistics describing the restructuring of the East German economy to put the decomposition analysis into perspective.

Our paper goes beyond the study by Hunt (2002), who reports a drop in the gender wage gap in East Germany right after unification, as well as the studies of Möller (2005), Kohn (2006), and Gernandt and Pfeiffer (2007, 2009), who also document rising wage dispersion in East Germany. Using IABS data, Möller (2005) looks at raw decile ratios of wage distributions for certain labor market groups, but he does not investigate the nature of observed differences by neither regression nor decomposition techniques. Kohn (2006), using the same data and employing the decomposition technique proposed by Machado and Mata (2005), attributes the major part of the increasing wage dispersion to endowment effects. The composition of the workforce only played a minor role. Gernandt and Pfeiffer (2007, 2009) and Hunt (2002) also employ wage regressions and decompositions, but their analysis is restricted by the small sample size of the GSOEP survey data, such that they have to rely on OLS regressions and the decomposition technique introduced by Juhn et al. (1991, 1993). As it turns out in the present study, the more flexible sequential decomposition techniques we use unveil important differences along the respective wage distributions. Our main findings are as follows:

First, an inspection of year-specific unconditional wage distributions for the different groups supports the notion of rising wage inequality in the first decade after unification. The interquintile range QD8020 for women rose by 29 log points between 1992 and 2001; the largest part of this considerable increase is due to rising wage dispersion in the lower part of the distribution. In contrast, the increase of the $Q D 8020$ by 16 log points for men during this period is mostly due to an increase of inequality in the upper part of the distribution of wages.

Second, for female workers, the large increase of wage inequality in the lower part of the distribution is partially explained by changes in individual-specific characteristics. This compositional effect is likely to reflect women's opting out of the labor force or changes into part-time work, as well as migration to West Germany and skill-upgrading. However, the major part of rising wage inequality in the lower part of the distribution is contributed by changing sector specific remuneration schemes, indicating a tendency 
towards an increasing wage flexibility across industries. The smaller increase of wage dispersion in the upper part of the distribution is attributed to the restructuring of the economy, as proxied by inter-industry shifts, as well as a general time trend.

Third, changes in the relative importance of certain sectors cause the structure of wages for female workers to polarize. Women located both at the lower and at the upper end of the wage distribution profit from these shifts relative to women located in the middle of the distribution. ${ }^{4}$ This polarization, which is likely to happen in fast motion in transition economies compared to mature market economies, is mirrored by employment shifts away from the manufacturing sector towards the service sector. However, we find that changes in industry coefficients alone would have caused wage dispersion in the upper part of the distribution to decline. This can be explained by the strong presence of unions in well-paying industries which seek to compress the sector-specific wage structure.

Fourth, for men, the rise in wage inequality is more pronounced in the upper part of the distribution. Changes in individual characteristics and a general time trend contribute the largest part to the increasing wage inequality throughout the entire distribution. Changes in individual and industry coefficients add somewhat to the increase of wage dispersion in the upper part.

Fifth, there exist important gender differences of the impact of the economic restructuring during the transition period. Changes in industry characteristics and their corresponding coefficients strongly alter the wage distribution of female workers, while being much less important for males. Hence, the sectoral transition affected women to a much larger extent than men. We provide evidence that substantial differences in the industry compositions of male and female workforce right after German reunification is the underlying reason for this finding. In particular, the stronger concentration of female workers in the public sector at the beginning of the observation period stands out.

The course of this paper is as follows. Section 2 reviews related literature and sketches the institutional background in Germany in the first years after unification. Section 3 introduces the data and offers a snapshot of raw wage distributions for different labor market groups as well as picture of the industry composition of the East German economy. Decomposition techniques for the setting at hand are introduced in section 4 . The subsequent discussion of results in section 5 scrutinizes patterns within the respective wage distributions and discusses underlying forces. Section 6 concludes while the appendix provides detailed descriptive statistics and estimation results, including robustness checks.

\footnotetext{
${ }^{4}$ The present study uses the term "polarization in wages" if the ratio of the upper quantile (e.g., the $80 \%$ quantile) and the median increases, while the ratio of the median and the lower quantile (e.g., the $20 \%$ quantile) is stable or even decreases. This is the same definition as in Antonczyk et al. (2010a).
} 


\section{Institutional Background and Related Literature}

Conventional wisdom holds that under socialist regimes wages are only little differentiated. Krueger and Pischke (1995) use the 1988 Survey on Income of Blue and White Collar Households in the GDR (Einkommensstichprobe in Arbeiter- und Angestelltenhaushalten) and the retrospective 1989 information of the 1990 German Socio-Economic Panel (GSOEP)-East to find a compressed wage structure in the late years of the GDR, implied by the egalitarian doctrine of the socialist system. Follow-up comparative studies using different GSOEP waves confirm this effect for the first years after the German unification. ${ }^{5}$ In particular, exceptionally flat age-earnings or experience-earnings profiles in the East are documented (see e.g. Orlowski and Riphahn, 2009; Kohn, 2006). These findings suggest that experience accumulated under the old system was poorly remunerated afterwards and that the unification shock led to a massive depreciation of human capital. However, as post-unification labor market cohorts started to age, wage dispersion increased in the first half of the 1990s (see Franz and Steiner, 2000; Burda and Hunt, 2001). ${ }^{6}$

Using administrative data, Möller (2005) documents rising wage inequality in East Germany throughout the 1990s. ${ }^{7}$ The author uses the years $1992-2001$ of the IABS to compare raw decile ratios of log wage distributions for some selective labor market groups. Starting at a lower level in 1992, wage inequality has largely caught up with the level of inequality in West Germany by 2001. ${ }^{8}$ Moreover, the rise in inequality has been more

\footnotetext{
${ }^{5}$ Schwarze and Wagner (1992), Schwarze (1993), and Bird et al. (1994) also use the retrospective information for 1989 in addition to waves up to 1991. Burda and Schmidt (1997) employ the waves 1990-1993. Steiner and Wagner (1997) and Franz and Steiner (2000) estimate wage regressions based on the waves 1990-1995 and 1990-1997, respectively. Burda and Hunt (2001) compare the waves 1990-1999 and Hunt (2001) studies wage growth and job mobility in East Germany based on the waves 1990-1996. She concludes that the observed wage growth patterns provided insufficient incentives for worker mobility, which impeded efficient restructuring and employment recovery.

${ }^{6}$ This observation is not restricted to East Germany. Brainerd (2000) looks at nine former communist countries, including Russia and the GDR, and documents that wage dispersion increased in all of them during the period of transition.

${ }^{7}$ Evidence from survey data in Gernandt and Pfeiffer $(2007,2009)$ suggests that this trend towards increasing inequality continued at least until the year 2004. Görzig et al. (2008) document that wage differentiation between firms in East Germany has also increased.

${ }^{8}$ The evolution of the West German wage structure between the mid-1970s and the mid-2000s has been extensively studied. Wage inequality in West Germany has been rising over the last 25 years (see e.g. Dustmann et al., 2009; Antonczyk et al., 2010a). Convergence of wages between the two parts of Germany has not yet been achieved, even though the West-East gap dropped considerably. The decline of this gap has been more pronounced among female workers (see e.g. Franz and Steiner, 2000; Kohn, 2006) and in general for the public service sector (Brenke, 2001). Still, our own calculations using the IABS data show that wages for male (female) workers in 2001 are 40 (18) log points higher in West Germany than in East Germany. Burda and Schmidt (1997), building upon a Blinder (1973)-Oaxaca (1973) decomposition and Steiner and Wagner (1997), employing a Juhn, Murphy, and Pierce (1993) decomposition, report a minor importance of differences in the characteristics of the work forces for the West-East wage gap. Likewise, the analysis of East-West migrants in Kirbach and Smolny (2004) also concludes that only a small part of observed West-East wage gaps can be attributed to observed socioeconomic characteristics of the workers. Görzig et al. (2008) provide evidence that the catching-up process in the East during the 1990s was in part offset by an increasing share of low-wage-type establishments in East Germany.
} 
pronounced for low-skilled compared to medium-skilled workers and for women compared to men. In fact, the level of wage inequality among women in East Germany now surpasses the one in the Western part (see also Franz and Steiner, 2000; Fuchs-Schündeln et al., 2010).

Net migration from the Eastern to the Western part of Germany between 1991 and 2004 amounts to 1.45 million people and the population in the East shrank from 14.5 million to 13.2 inhabitants between 1991 and 2006 (Fuchs-Schündeln et al., 2010). A first wave of migration took place directly after the German reunification. A second wave picked up by the late 1990s. The propensity to migrate declines with age, and this effect is even more pronounced in the second wave. While migrants have become more educated over time (Fuchs-Schündeln and Schündeln, 2009), evidence for the existence of a brain drain is mixed (Arntz, 2010). However, if emigration from East Germany during the observation period is skill- or age-biased, i.e., if migrants are in fact either better educated workers or low-skilled workers who have been laid-off (Hunt, 2006), the observation that wage inequality increases faster in East Germany than in West Germany is even more remarkable.

Changes of labor force participation rates also played a role in explaining the documented wage changes. In particular, the participation rate of female workers declined in the aftermath of German reunification (see e.g. Franz and Steiner, 2000). Hunt (2002) estimates that involuntary exits from employment are responsible for half of the ten percent drop of the gender wage gap between 1990 and $1994 .^{9}$

Occupational and sectoral segregation is a further possible cause for the different trends in wage inequality experienced by males and females. As in most central and eastern European countries, such a segregation by gender existed in the GDR. ${ }^{10}$ Despite the fact that public childcare was widespread in East Germany, women selected themselves into occupations which provided better possibilities than others to raise children. In addition, freedom of occupational choice in East Germany was limited. For example, access to the last two years of high school, which was a necessary condition for attending university, was restricted to a certain share of students. ${ }^{11}$ One main feature of the occupational segregation in Eastern Europe, distinguishing it from the Western world, was that "patri-

\footnotetext{
${ }^{9}$ The author uses the GSOEP and estimates that the average gender wage gap in 1994 was $16 \%$. Brainerd (2000) documents a decline in the gender wage gap across Eastern Europe between 1990 and 1994, with the exception being Russia and the Ukraine.

${ }^{10}$ Our data (see tables 1 and 2 ) show that in 1992, 22 percent of women were employed in producing sectors (sectors 1-8) compared to 54 percent of male workers.

${ }^{11}$ Family background and the "correct" political opinion, in addition to academic qualification, were some of the criteria (Fuchs-Schündeln and Schündeln, 2005).
} 
archal stereotypes were institutionalized through official attitudes and policies" (Oglobin, 1999). ${ }^{12}$

Finally, there exists a strand of literature pointing out the role of unions for explaining changes in labor market trends in economies of transition. Under communism wages had been set centrally. Shortly after German reunification, labor unions from West Germany started bargaining wages with East German firms, which had only partly been privatized yet. Thus, the West German model of wage negotiations was applied "improperly" to East Germany, as the capital was not represented by capitalists (Scheremet, 1995). In fact, large wage increases were negotiated with the aim to achieve parity with wages in West Germany by 1994. This goal was motivated by political reasons and did not match increases in productivity. ${ }^{13}$ As economic conditions continued being poor, firms soon started to opt out of the bargaining system altogether (see e.g. Hunt, 2001; Bonin, 2005). This opting out has not been at all uniformly distributed though, with some selective sectors keeping up high coverage rates of up to 90\% (Franz and Steiner, 2000; Bonin, 2005). ${ }^{14}$

\section{Stylized Facts}

Our study uses the regional file of the IAB employment sample (IABS) 1975-2001. Information on East Germany is included from 1992 onwards. This version of the IABS is a $2 \%$ random sample of German social security records. ${ }^{15}$ The IABS covers about $80 \%$ of all employed persons, excluding mainly self-employed workers and civil servants. This data-set offers a large sample size and - due to its administrative character - a highly reliable quality of data. In particular, the wage data are very accurate compared to survey data and the sector variable is consistently estimated over time. ${ }^{16}$ On the downside, the data set provides only daily wages and no information on working time except for a

\footnotetext{
${ }^{12}$ Oglobin (1999) further remarks that, at least in the Soviet Union, patriarchal stereotypes, which valued labor of men higher than labor of women, coincided with "the principles of Marxist political economy, according to which the production of means of production is superior to the production of consumer goods, and the so-called "nonproductive sphere" (healthcare, education, personal services) has the lowest priority."

${ }^{13}$ Sinn (1997) points out that East Germany was a special case in this respect. While most other countries in central and Eastern Europe experienced real wage losses during the period of transition, East German workers experienced real wage gains during the first years after the German reunification. The author further argues that this comes at the cost of a disproportionately sharp decline of industry production.

${ }^{14}$ It is likely that the process of opting out of collective wage bargaining agreements was favored by the strong decline in union membership rates in East Germany during the 1990s. The share of unionized employees dropped from 37\% in 1993 to $18 \%$ in 2003 (Fitzenberger et al., 2011).

${ }^{15}$ See Hamann et al. (2004) for a description of the data set. For further information (on antecedent versions of the IABS), see also Bender et al. (2000).

${ }^{16}$ The sector variable allows the distinction of 16 different sectors, which are defined in tables 1 and 2 .
} 
distinction between full-timers and part-timers. ${ }^{17,18}$ Besides, the wage data are top-coded at the social security taxation threshold (SSTT). ${ }^{19}$

We consider separate distributions for men and women working full-time in East Germany in the years 1992 and 2001. For each of these subsamples, we select individuals aged between 25 and 55 years who are currently not in education. Part-time workers are not included in the analysis as we cannot identify hours of work and have only information on daily wages. Moreover, we want to avoid spurious effects through employment changes in this group. Tables 1 and 2 describe the subsamples by gender in each of the years. Skill upgrading took place between 1992 and 2001. Yet as the share of low-skilled workers decreased among both men and women, the proportion of high-skilled workers went up more strongly among female workers. With respect to changes in the industry structure of the work force, employment in public and social security system services (sector 16) decreased most strikingly.

\section{[Tables 1 and 2 about here]}

Figure 1 shows kernel density estimates of real log wages for full-time working female and male workers in 1992 and 2001. The dashed vertical line in these graphs shows the social security threshold, above which wages are imputed. It can be directly inferred from these graphs that the distributions are more dispersed in 2001 than in 1992.

\section{[Figure 1 about here]}

Figure 2 sketches unconditional wage growth between 1992 and 2001 at different quantiles of the wage distribution. For male workers, wages at all considered quantiles $(20 \%$, $50 \%$, and 80\%) grow until 1996. Afterwards, the upper quantile continues to increase, while wages at the median plateau and wages at the lower quantile begin to incur real wage losses. Wage dispersion in both parts of the distribution increase throughout the entire period. However, the cumulated increase of the difference between the $80 \%$ quantile

\footnotetext{
${ }^{17}$ Full-timers in the IABS are those employees working a minimum of 30 hours per week.

${ }^{18}$ Dustmann et al. (2009) provide evidence that results on wage inequality are robust to either using data from the GSOEP and considering hourly wages or using the information provided by the IABS and considering daily wages.

${ }^{19}$ The top-coding affected 18.7 percent (13.1 percent) of wages of male (female) workers in the year 1992. In subsequent years the SSTT increased faster than real wages, and so only 6.8 percent (3.6 percent) of wages of male (female) workers were censored from above in the year 2001. We use the approach suggested by Gartner (2005) to impute wages above the SSTT. This is a homoscedastic single imputation approach which is based on a Tobit model. Wage predictions and estimation results above the SSTT are reported. Of course, they have to be interpreted with some caution. As a robustness check for our results in section 5, we also carry out censored quantile regressions. Results in the region below the censoring points are nearly identical to those obtained from using quantile regression with imputed wages, and therefore are not reported here. As censored quantile regressions are computationally highly demanding, we prefer using imputed wages in the censored region to carry out our analysis.
} 
and the $50 \%$ quantile of $\log$ wages $(Q D 8050,+10 \log$ points $)$ is larger than the increase of the difference between the median and the $20 \%$ quantile $(Q D 5020,+6$ log points).

\section{[Figure 2 about here]}

For female workers, wages at the lower quantile move sideways until 1996 and then decline. Wages at the median increase until the middle of the observed period and plateau afterwards. Again, wages at the $80 \%$ quantile increase throughout the entire period. However, in contrast to men, for female workers the rise in overall wage dispersion is largely driven by the increase of $Q D 5020$ ( $+20 \mathrm{log}$ points), while $Q D 8050$ increases by only 9 log points. ${ }^{20}$ Finally, tables 1 and 2 summarize the evolution of the QD8050 and the $Q D 5020$ within sectors by gender, as well as the general wage trend within sectors, as approximated by the wage growth at the median. In particular, for female workers it stands out that the largest sector in 1992, public services, exhibited increasing wages along the entire distribution while the sector specific wage dispersion is astonishingly stable.

Table 3 measures the gender wage gap in 1992 and 2001 at all deciles. For both years, the gender wage gap is largest at the lower end of the distribution, which is prima facie evidence of a "glass floor" effect for female employees. On the other hand, note that the gender wage gap at the median and at the $70 \%$ percentile has disappeared entirely by 2001. The glass floor effect stands somewhat in contrast to the interpretation of Hunt (2002), who argues that the fall of the gender wage gap is driven by job losses of low-paid women. ${ }^{21}$ For the period 1992-2001, women at the top of the distribution outperform men, while women at the bottom of the distribution lose some ground.

\section{[Table 3 about here]}

In order to investigate sectoral segregation by gender and to infer how the restructuring of the economy affected different sectors, figures 3 and 4 depict relative employment growth within industries between 1992 and 2001. Industries are ranked according to real median wages paid in 1992 and the relative change of employment is measured as the sum of spell durations (in days) in 2001 divided by the sum of spell durations in 1992. The

\footnotetext{
${ }^{20}$ Wages changed rather smoothly over the period 1992-2001, so it makes sense to focus on the two limiting years. This is also warranted for the following reasons. The labor force in East Germany dropped sharply from about 10 to below 7 million in the course of the German unification and most of the immediate downturn took place in 1990 and 1991; see Kommission (1996). Net emigration from East Germany was highest between 1989 and 1991; see Hunt (2006). 1992 was the first year with a positive GDP growth in East Germany after the unification shock (Burda and Hunt, 2001) and thus is the first year not heavily exposed to distortions resulting from the unification. Finally, both years are similar with respect to their location in the (West) German business cycle: Whereas the unification boom faded out in 1992, the year 2001 marked the end of the new economy boom.

${ }^{21}$ However, the study by Hunt considers an earlier period (1990-1994) and uses the GSOEP survey data.
} 
highest rank (16) is given to the industry paying the largest median wage in 1992 . The size of the circles indicates the importance of the sector (measured as the sum of spell durations over both years).

[Figures 3 and 4 about here]

For male workers, the change in employment is rather uniform across industries, i.e., there is no systematic pattern linking it to the ranking of industry-specific median wages in 1992. In contrast, changes in employment of female workers show a somewhat U-shaped pattern. Industries with median wages located at the boundaries of the wage distribution in 1992 do better in terms of employment growth, relative to industries whose median wage is located in the middle of the wage distribution. Three out of the four industries with the largest relative growth are service industries. Sectors in production, which require a lot of routine-manual tasks, did extremely poor. Thus, we detect a pattern of employment polarization following German reunification. This suggests that the restructuring of the East German economy is at least to some extent demand-side driven, away from the manufacturing sector towards the service sector. ${ }^{22}$ A further (complementary) interpretation is that no actual market for services existed in the GDR (see footnote 12), and that once market forces were free to act, women more than men went into these occupations, as they might have a comparative advantage in people skills (see Borghans et al., 2006, for evidence along this line of argument). ${ }^{23}$

\section{Decomposing Differences Across Wage Distribu- tions}

In this paper, we seek to analyze effects along the entire distribution of wages. Quantile regressions are particularly well suited for this purpose, because they do not only reveal differences between, say, different skill or age groups, but also allow these differences to

\footnotetext{
${ }^{22}$ Considering industrialized countries such as the US, the UK, or West Germany, the task-based approach, i.e., a more nuanced version of the skill-biased technical change hypothesis, argues that due to technical advancement, labor demand shifts from routine-jobs to jobs involving more non-routine tasks. Such shifts favor (in terms of employment and/or wage growth) jobs located at both ends of the wage distribution relative to jobs located in the middle (see e.g. Autor et al., 2008; Goos and Manning, 2007; Spitz-Oener, 2006; Antonczyk et al., 2009).

${ }^{23}$ In general, changes in the relative importance of occupations as well as industries happen in fast motion in transition economies compared to mature market economies. In fact, the heavily outdated industry structure in many Eastern European countries was one of the reasons why the Eastern bloc collapsed in the first place.
} 
vary across the wage distribution. We specify the $\tau$ th quantile of log hourly wages $w$ conditional on the set of covariates $X$ as

$$
\text { (1) } \quad q_{w}(\tau \mid X)=X^{\prime} \beta(\tau)
$$

and estimate extended Mincer-type wage equations. These include a set of formal skill dummies (low-skilled $d_{l}$ : workers without vocational training and without university degree, medium-skilled (base category): those with vocational training and no university degree, and high-skilled $d_{h}$ : employees with university or technical college degree), ${ }^{24}$ (normalized) age, and age squared (agesq). In order to allow for different age-earnings profiles across skill groups, we include interaction terms of skill and age as well as skill and agesq. This yields the following specification to be estimated for each gender at point in time $t::^{25}$

$$
\begin{aligned}
q_{w}(\tau \mid X)= & \beta_{1 t}+d_{l, t} \beta_{2 t}+d_{h, t} \beta_{3 t}+\operatorname{age}_{t} \beta_{4 t}+\operatorname{agesq}_{t} \beta_{5 t} \\
& +d_{l, t} \text { age }_{t} \beta_{6 t}+d_{l, t} \operatorname{agesq}_{t} \beta_{7 t}+d_{h, t} \operatorname{age}_{t} \beta_{8 t}+d_{h, t} \operatorname{agesq}_{t} \beta_{9 t}+u_{t} .
\end{aligned}
$$

All regressions further include a set of industry dummies (16 industries as provided with the IABS) and a dummy for individuals working in Berlin. Observations are weighted by the length of the respective employment spells. ${ }^{26}$

Decomposition analyses answer the question whether differences in observed distributions result from differences in estimated coefficients or from differences in the composition of the workforce. We focus on changes of the respective wage structures over time. A Blinder (1973)-Oaxaca (1973)-type decomposition (B-O) for the difference between the expected wages in two periods $t$ and $t^{\prime}$ reads

$$
E\left(Y_{t} \mid X_{t}\right)-E\left(Y_{t^{\prime}} \mid X_{t^{\prime}}\right)=\left(X_{t}-X_{t^{\prime}}\right) \beta_{t}+X_{t^{\prime}}\left(\beta_{t}-\beta_{t^{\prime}}\right)
$$

The first summand on the right hand side of equation (3), traditionally labeled "characteristics effect", captures the part of the difference that is attributable to differences in the covariates across the two periods. The second summand, known as "returns" or "coefficients effect", captures the part of the difference that is attributed to differences in the returns to the covariates. The resulting counterfactual $X_{t^{\prime}} \beta_{t}$ hypothesizes what the

\footnotetext{
${ }^{24}$ In order to deal with measurement error in the education variable when defining skill groups, we use the procedure suggested by Fitzenberger et al. (2006).

${ }^{25}$ For ease of notation we use $\beta$ instead of $\beta(\tau)$ in formula (3).

${ }^{26}$ Due to space constraints we do not display the estimation results of the quantile regressions here. These are available upon request. Gender-specific summary statistics of the covariates are displayed in tables 1 and 2 .
} 
expected wage would have been in face of returns in the year $t$, had the distribution of characteristics not changed since $t^{\prime} .^{27}$

A further method introduced by Juhn et al. (1991), applied in a series of papers by Blau and Kahn $(1992,1994,1997)$ also decomposes the change in a wage gap over time. This approach has got the additional merit that it further decomposes residual effects into a quantity and a price effect. However, it suffers from the shortcoming that it assumes unique coefficients across periods $t$ and $t^{\prime}$. Furthermore, the decomposition of the residual terms is inapplicable in the case of censored data, in which residuals can only be used for uncensored observations. There are also alternative approaches in the literature for decomposing differences across entire distributions. The decomposition introduced by Juhn, Murphy, and Pierce (JMP, 1993) employs the distribution of residuals resulting from wage regressions to rank observations. This approach gives a structural interpretation to the regression residual. ${ }^{28}$ Nonetheless, it faces a couple of shortcomings. First, its focus on the distribution of residuals renders the approach as inapplicable in the case of censored data as the related (1991) approach. Second, even without censoring of the data, the JMP decomposition is valid only in the case of homoscedasticity, which is usually rejected for empirical wage regressions. Third, it is more restrictive than the techniques building upon quantile regressions as it assumes a single linear model to hold for the entire wage distribution. In contrast, approaches based on quantile regressions allow for flexibility across the distribution.

In this study, we start by using the Machado and Mata (2005) decomposition approach for quantile regression, which is an extension of the standard B-O decomposition technique presented above. For the analysis of changes in the wage structure over time, one can decompose the difference of the unconditional sample quantile functions for the $\tau^{\text {th }}$ quantile between workers in $t=2001$ and workers in $t^{\prime}=1992$ (denoted by $\hat{q}_{01}(\tau)$ and $\left.\hat{q}_{92}(\tau)\right)$ as follows:

$$
\hat{q}_{01}(\tau)-\hat{q}_{92}(\tau)=\left[\hat{q}_{01}(\tau)-\hat{q}_{\beta_{01}, x_{92}}(\tau)\right]+\left[\hat{q}_{\beta_{01}, x_{92}}(\tau)-\hat{q}_{92}(\tau)\right]
$$

Similar to the B-O decomposition, the term in the first brackets on the right hand side of $(4)$ is a characteristics effect, and the one in the second brackets a returns effect. $\hat{q}_{\beta_{01}, x_{92}}(\tau)$ is the estimated counterfactual quantile function denoting wages that would be generated

\footnotetext{
${ }^{27}$ It is well known that the partition depends on the ordering of the effects and that the decomposition results may not be invariant with respect to the choice of the involved counterfactual $X_{t^{\prime}} \beta_{t}$; see the survey of Oaxaca and Ransom (1994). Therefore, the choice of a counterfactual should be guided by economic interest.

${ }^{28}$ Blau and Kahn (1996) use this method for cross-country comparisons, Steiner and Wagner (1997, 1998) and Gernandt and Pfeiffer (2007) apply it to German data.
} 
for workers from 1992, were they paid according to 2001 remuneration schemes. ${ }^{29}$ With respect to the choice of a counterfactual distribution the same caveat as in the $\mathrm{B}-\mathrm{O}$ case applies. $^{30}$

Our implementation of the Machado and Mata (2005) decomposition follows the approach proposed by Melly (2005) for greater ease of computation. ${ }^{31}$ This approach is also used by, e.g., Burda et al. (2008) and Antonczyk et al. (2010b). We refer to these three studies for discussions of implementation details. In order to assess the importance of various components of the characteristics and coefficients effects, we estimate a sequence of counterfactual wage distributions. We incrementally change the distribution of the subsets of covariates for the characteristics effects and of the subsets of the corresponding coefficients, holding all other components constant. While further decomposing the characteristics and coefficients effects, this approach accounts for the observed joint sample distribution of characteristics in the reference year when estimating counterfactual combinations. Effects on changes of the wage structure are therefore defined as differences between clearly defined counterfactuals.

The quantiles of the observed wage distributions for the two cross-sections of data in 1992 and 2001 are expressed as follows:

$$
q_{\tau}^{01}\left(\alpha_{P}^{01}, \alpha_{I}^{01}, \bar{\alpha}_{0}^{01}, I^{01}, P^{01}\right) \quad \text { and } \quad q_{\tau}^{92}\left(\alpha_{P}^{92}, \alpha_{I}^{92}, \bar{\alpha}_{0}^{92}, I^{92}, P^{92}\right)
$$

where $P$ and $I$ denote sets of individual (or personal) and industry characteristics and $\alpha_{P}$ and $\alpha_{I}$ refer to the corresponding sets of coefficients. ${ }^{32}$ These different components set the foundation for the following sequential decomposition, which separately analyzes the contribution of each of the arguments in order to explain gender-specific changes in the wage distributions over time. For a meaningful analysis of the change in intercepts, we

\footnotetext{
${ }^{29}$ Autor et al. (2005) also build on the approach suggested by Machado and Mata, while DiNardo et al. (1996) exploit kernel density estimations to decompose differences in a nonparametric setting. Compared to the latter approach, the semiparametric Machado and Mata framework is restrictive by nature. Yet, by quantifying differences in the coefficients it sheds light on that part of a difference which would be left unexplained in the nonparametric framework.

${ }^{30}$ The underlying assumption for the estimation of a counterfactual wage distribution is that a change in the covariates $X$ will not change the parameters of the conditional distribution of $w$, given covariates $X$ (e.g. Chernozhukov et al., 2008), i.e., general equilibrium effects are ignored by assuming that changes in quantities (characteristics effect) do not affect changes in prices (coefficients effect). Analogous assumptions are made by alternative decomposition techniques (see e.g. DiNardo et al., 1996).

${ }^{31}$ In each year-by-gender cell, we estimate 99 equispaced quantile regressions in order to approximate the respective conditional distribution functions.

${ }^{32}$ We use the observed wage distributions in 1992 and 2001 for $q_{\tau}^{92}$ and $q_{\tau}^{01}$ in equation (5). However, as discussed by Melly (2005), one could also estimate the observed distribution based on the quantile regression estimates.
} 
normalize all covariates with respect to their 1992 means. Our sequence of counterfactuals reads as follows:

$$
\begin{aligned}
\Delta_{\tau}^{1} & =q_{\tau}^{01}\left(\alpha_{P}^{01}, \alpha_{I}^{01}, \bar{\alpha}_{0}^{01}, I^{01}, P^{01}\right)-q_{\tau}^{92}\left(\alpha_{P}^{01}, \alpha_{I}^{01}, \bar{\alpha}_{0}^{01}, I^{01}, \mathbf{P}^{\mathbf{9 2}}\right) \\
\Delta_{\tau}^{2} & =q_{\tau}^{92}\left(\alpha_{P}^{01}, \alpha_{I}^{01}, \bar{\alpha}_{0}^{01}, I^{01}, P^{92}\right)-q_{\tau}^{92}\left(\alpha_{P}^{01}, \alpha_{I}^{01}, \bar{\alpha}_{0}^{01}, \mathbf{I}^{\mathbf{9 2}}, P^{92}\right) \\
\Delta_{\tau}^{3} & =q_{\tau}^{92}\left(\alpha_{P}^{01}, \alpha_{I}^{01}, \bar{\alpha}_{0}^{01}, I^{92}, P^{92}\right)-q_{\tau}^{92}\left(\alpha_{\mathbf{P}}^{\mathbf{9 2}}, \alpha_{I}^{01}, \bar{\alpha}_{0}^{01}, I^{92}, P^{92}\right) \\
\Delta_{\tau}^{4} & =q_{\tau}^{92}\left(\alpha_{P}^{92}, \alpha_{I}^{01}, \bar{\alpha}_{0}^{01}, I^{92}, P^{92}\right)-q_{\tau}^{92}\left(\alpha_{P}^{92}, \alpha_{\mathbf{I}}^{\mathbf{9 2}}, \bar{\alpha}_{0}^{01}, I^{92}, P^{92}\right) \\
\Delta_{\tau}^{5} & =q_{\tau}^{92}\left(\alpha_{P}^{92}, \alpha_{I}^{92}, \bar{\alpha}_{0}^{01}, I^{92}, P^{92}\right)-q_{\tau}^{92}\left(\alpha_{P}^{92}, \alpha_{I}^{92}, \bar{\alpha}_{\mathbf{0}}^{\mathbf{9 2}}, I^{92}, P^{92}\right)
\end{aligned}
$$

The first step consists of changing the individual-specific characteristics from their 2001 levels to their counterparts from 1992; the last part determines the residual change. Just as with extended B-O-type decompositions, the order of the sequential decomposition steps matters. A different order corresponds to a different sequence of counterfactuals and our interpretation of results is specific to the chosen sequence of counterfactuals. The choice of the sequence should thus be guided by economic reasoning. Since the focus of this study is on the transformation process, we consider it natural to take the perspective of individuals from 1992: These are the ones being affected by the shock of transformation. ${ }^{33}$

The first component of our decomposition sequence is $\Delta_{\tau}^{1}$, estimating the impact of changes in observable individual-specific characteristics. However, changing the characteristics sequentially is not straightforward, as we want to take the joint sample distribution of the observable covariates into account. In order to mimic the industry structure from 2001 for individuals from 1992, we use exact one-to-one matching with replacement on the basis of individual-specific characteristics and assign each individual from 1992 to a statistical twin in 2001. This takes account of the selection process (in 2001) of individuals into industries based on observable (individual) characteristics.

The next step of the decomposition involves the change in industry characteristics $I$ $\left(\Delta_{\tau}^{2}\right)$, which completes changes of the observable characteristics.

Having altered the covariates to the 1992 level, we continue by changing the corresponding coefficients. The first component is $\Delta_{\tau}^{3}$, estimating the impact of changes in returns to observable individual characteristics.

The next step changes the returns to industry characteristics. This yields the counterfactual wage distribution for individuals in 1992, as if they were exposed to the labor market remunerations in 2001, in terms of both individual and industry coefficients $\left(\Delta_{\tau}^{4}\right)$.

The change of the average constant $\bar{\alpha}_{0}$ from $\bar{\alpha}_{0}^{92}$ to $\bar{\alpha}_{0}^{01}$ represents the residual change in the overall wage level over time, which cannot be explained by the variables included

\footnotetext{
${ }^{33}$ In addition, we also estimate an alternative sequence of our decomposition as a robustness check. The results, which are reported in the appendix, do mostly not change qualitatively.
} 
in our model $\left(\Delta_{\tau}^{5}\right)$. The complete sequential decomposition of the changes between 1992 and 2001 can be summarized as follows:

$$
\begin{aligned}
& \Delta_{\tau}^{01 / 92}=q_{\tau}^{01}\left(\alpha_{P}^{01}, \alpha_{I}^{01}, \bar{\alpha}_{0}^{01}, F^{01}, P^{01}\right)-q_{\tau}^{92}\left(\alpha_{P}^{92}, \alpha_{I}^{92}, \bar{\alpha}_{0}^{92}, I^{92}, P^{92}\right) \\
& =\underbrace{\underbrace{\Delta_{\tau}^{1}}_{\text {Individual }}+\underbrace{\Delta_{\tau}^{2}}_{\text {Industry }}}_{\text {Characteristics }}+\underbrace{\underbrace{\Delta_{\tau}^{3}}_{\text {Industry }}}_{\text {Coefficients }}+\underbrace{\Delta_{\tau}^{4}}_{\text {Individual }}+\underbrace{\Delta_{\tau}^{5}}_{\text {Residual }}
\end{aligned}
$$

We implement the decomposition separately for female and male employees. ${ }^{34}$

\section{Decomposition Results}

As discussed in section 2, real wages for male workers increase along the entire distribution between 1992 and 2001, while only women located above the $30 \%$ percentile of the wage distribution experience gains during this period. Moreover, the data indicate rising wage dispersion by gender. For females, the $80-20$ difference rises by $29 \log$ points. This is largely driven by an increasing dispersion of wages in the lower part of the distribution (the 50-20 difference rises by 20 log points), while the increase in inequality in the upper part of the distribution is considerably smaller (the 80-50 difference rises by 9 log points), see the first row of table 4. In contrast, for male workers, the overall increase of the 80-20 difference $(+16 \log$ points $)$ is mostly driven by changes in the 80-50 difference $(+10 \mathrm{log}$ points), while the 50-20 difference contributes $6 \log$ points, see the first row of table 5 .

\section{[Tables 4 and 5 about here]}

Figure 5 illustrates the results of the Machado-Mata decompositions, yielding aggregate characteristics and coefficients effects. For both males and females, the characteristics effect causes wages below the median to decrease (-2 log points at the $20 \%$ quantile for males, $-7 \log$ points for females) and to increase in the region above the median $(+4$ $\log$ points at the $80 \%$ quantile for males, $+2 \log$ points for females). The coefficients effect dominates in explaining the total change of wages between 1992 and 2001 for both genders. This decomposition already reveals important heterogeneous effects along the wage distribution. In particular, related studies in the literature, which mostly use the more restrictive $\mathrm{B}-\mathrm{O}$ or JMP decompositions for different periods of time, find basically no composition effects among prime-age employees. ${ }^{35}$ In contrast, our results show that

\footnotetext{
${ }^{34}$ Even though our analysis focusses on East Germany, we also implement an analogous decomposition for West Germany for comparison reasons. Results are available upon request.

${ }^{35}$ Burda and Hunt (2001) apply B-O decompositions to the GSOEP East 1990-1999. Gernandt and Pfeiffer (2007) also use GSOEP data for 1984-2004 and apply JMP decompositions. As an exception, Kohn (2006) uses the decomposition technique proposed by Machado-Mata. His findings are broadly in line with ours.
} 
the characteristics of the workforce changed in way such that it increased wages in the upper part of the wage distribution and decreased wages in the lower part.

\section{[Figure 5 about here]}

We now turn to the sequential decomposition method. This allows us to disentangle the effects stemming from changes in individual characteristics from those which are due to changing industry characteristics, as well as their corresponding coefficients effects. In fact, the two characteristics effects may cancel each other out in a more standard framework. Tables 4 and 5 summarize our estimates for the impact on overall wage dispersion (80-20 differential), as well as on wage inequality in the upper and the lower parts of the wage distribution (as measured by the 80-50 and 50-20 differentials, respectively). Figures 6 and 7 display changes along the entire wage distribution. ${ }^{36}$

For women, the increase of the 50-20 differential is almost entirely explained by changes in individual characteristics $(+5.7$ log points) and changes in industry coefficients $(+12$ log points; table 4). Changes in other components seem to be of minor importance. The smaller increase of the 80-50 differential is driven by inter-industry shifts (+6.8 log points) as well as the residual component ( +5.6 log points). Changes in individual characteristics and changes of the industry coefficients alone would have caused the $80-50$ difference to decline.

For men, changes in individual characteristics $(+2.7$ log points $)$ partially explain the increase of the 50-20 differential, while changes in industry coefficients work in the opposite direction (-1.8 log points; table 5). The residual effect $(+4.6 \log$ points) contributes the single largest component to this increase. The rise of the 80-50 differential is explained by changes in individual characteristics $(+5 \log$ points), as well as changes in individual coefficients $(+1.5 \mathrm{log}$ points $)$ and industry coefficients $(+1.6 \log$ points). Once again, a large part is contributed by the residual component $(+7.7 \log$ points).

\section{[Figures 6 and 7 about here]}

\section{Individual-specific characteristics}

Changes in individual-specific characteristics, which involve age, education, and corresponding interaction terms, may reflect (observable) skill-upgrading during the period, emigration, and - presumably in particular for females - the possibility that lesser skilled workers opted of the labor force or changed into part-time work (cp. also Hunt, 2002). Due to changes in individual characteristics, wages of female workers rise significantly

\footnotetext{
${ }^{36}$ For the interpretation of the results, note that an upward (downward) sloping line in figures 6 and 7 represents a situation where the corresponding component of the decomposition is associated with an increase (decrease) in overall wage inequality. This is because the implied change in wages is greater (smaller) at higher quantiles as compared to lower quantiles.
} 
along the entire distribution, with the largest gains being centered in the region around the median. The smallest gains are estimated within the lower regions of the distribution. Changes in individual characteristics thus contribute to the rising wage dispersion in the lower part of the distribution. Men also gain due to changes in individual characteristics, though to a lesser extent. For example, at the median, wages for males (only) increase by $3 \log$ points due to these compositional changes of the workforce - as compared to an increase of $6 \log$ points for female workers. Changes in individual characteristics are thus able to explain a decline of $3 \log$ points of the gender wage gap at the median (of a total decline of $6 \log$ points, see table 3). Interestingly, Hunt (2002), considering the period from 1990 to 1994, also documents that about half of the drop of the gender wage gap is due to (individual) compositional effects. She attributes this finding to the withdrawal of lesser skilled women from the labor force. In this respect, our results corroborate her notion.

\section{Industry characteristics}

Changes in industry characteristics as measured by sector dummy variables reflect the restructuring of the East German economy by means of inter-industry shifts. ${ }^{37}$ For women, restructuring led to significantly lower wages along the entire distribution. Thus, a preferable wage structure for individuals from 1992 would have evolved if the industry structure had stayed the same as in 1992 (but individuals had been paid as in 2001). However, there are pronounced differences along the distribution. Wages decrease strongest for female workers below the median and evolve most positively for workers at the upper end of the distribution. We estimate a U-shaped pattern. This implies that changes in the industry-composition alone would have led to a polarization of wages among female workers, causing wage dispersion in the upper part of the distribution to increase and inequality in the lower part to decline.

What explains this polarizing pattern? The descriptive statistics in table 1 indicate that service sectors grew most substantially. The estimated effect might thus capture the impact of a shift from manufacturing towards a more service-oriented structure of the economy (see also Hunt, 2001). This shift seems to hurt especially workers in the lower middle of the distribution of wages, where workers carrying out routine tasks tend to be located (see the discussion in section 3). Women above the median also lose, but to a lesser extent. The fall in the upper part is likely to be triggered by the decline of employment in the public service sector. However, it seems to be counteracted to some

\footnotetext{
${ }^{37} \mathrm{~A}$ dummy variable for Berlin is also included in the regression. Due to the fact that Berlin was divided into a Western and an Eastern part prior to the German reunification, we control for whether a worker is employed in Berlin. Only workers in East Berlin are included in our regressions. Carrying out the analysis without Berlin yields nearly identical results.
} 
extent by the relative increase of the medical service sector - these two sectors are the ones paying highest median wages in 2001.

Comparing figures 3 and 4 reveals that inter-industry shifts in employment have been much less uniform for female workers than for male workers. These different sectoral shifts seem to be the underlying reason why the restructuring of the economy affected men and women in quite a different manner. ${ }^{38}$ In fact, wages for male workers along the entire wage distribution also decline due to restructuring, but here losses are largest at the bottom of the distribution and monotonically decline when moving up the wage distribution. This results in small increases in wage dispersion especially in the upper part of males' wage distribution. In summation, changes in the relative importance of certain sectors affect women to a much larger extent than men. ${ }^{39}$ Overall, the restructuring favors male workers relative to female workers along the entire wage distribution, with largest relative gains for men at lower deciles.

\section{Time trend}

The residual effect can be interpreted as a general time trend. This trend captures the part stemming from a variety of (unobserved, i.e., not captured by our specification) changes that have taken place in the years following German reunification. These factors include, e.g., deunionization. The level of the residual effect is considerable for both genders. Yet the trend is only of minor importance for explaining the increase in inequality in the lower part of women's wage distribution. It does contribute to the rising wage dispersion in the upper part of the distribution to a greater extent. Still, our specification explains the major part of the increase in wage dispersion throughout the entire distribution (see table 4). For male workers, the results regarding wage dispersion are qualitatively similar to those for females; we estimate a trend towards greater inequality. In fact, the residual part explains a considerable share of the rising wage dispersion along the entire male wage distribution. Comparing the two estimated effects across gender, we find that in particular women below the median benefit from the general time trend relative to men.

\section{Individual-specific coefficients}

For female workers, changes in the coefficients of individual characteristics exclusively raise wages slightly at the very top of the distribution. They do neither affect the level nor the dispersion of wages significantly in the other parts of the distribution. For males, wages in the lower region of the distribution uniformly decline slightly due to changes in individual coefficients, while the wage level and wage dispersion in the upper part of

\footnotetext{
${ }^{38}$ Note that this assessment differs from Hunt's (2002) conclusion.

${ }^{39}$ Again, these changes arguably happen in fast motion compared to changes in mature market economies.
} 
the distribution increase. These results are qualitatively in line with those of Orlowski and Riphahn (2009), who, using GSOEP data, consider male workers and report rather flat experience-earnings profiles in the years right after German reunification, which then increased during the 1990s. Yet for female workers the coefficients neither change within nor between skill-groups in a way promoting greater wage flexibility.

\section{Industry coefficients}

For female workers, changes of industry coefficients lead to rising wages in the middle of the distribution, decreasing wages at the lower end, and somewhat increasing wages for workers at the upper deciles. We thus obtain an inverted U-shape pattern for this effect along the distribution of wages. Hence, changes in industry coefficients alone would have caused increasing dispersion in the lower part of the distribution, and decreasing inequality in the upper part. In fact, for the lower part of the distribution, this effect explains more than half of the total increase. As we estimate quantile regressions, changes in industry specific premia may reflect a tendency towards increasing wage flexibility within as well as between industries. The between effect is likely to be due to the large increase of median wages for the medical as well as the public services sectors, which comprise more than 40 percent of female workers in $1992 .{ }^{40}$ Wages at the median for these two sectors lie already above the overall median in 1992 and experience above-average wage growth thereafter. In addition, we observe that within-wage dispersion for these two sectors did hardly increase. One obvious reason, at least for the public service sector, is that most employees in this sector were covered by collective wage bargaining agreements (see Franz and Steiner, 2000). These agreements are likely to induce general wage increases for the entire sector, without within sector wage differentiation. This notion also helps to explain why we estimate decreasing wage dispersion in the upper part of the wage distribution. Another reason for the decline of the 80-50 difference is the notion that some sectors' wages might have gone up at upper quantiles before 1992, while other sector-specific remuneration schemes caught up only afterwards(see Franz and Steiner, 2000). In particular, while the highest-paying jobs within industries may have received considerable wage increases already in the very early phase after reunification, jobs at the middle of the wage distribution may have risen with some more delay.

Once more, male workers are affected in a completely different way. Changes in industry specific remuneration schemes lead to somewhat higher wages at both ends of the distribution, relative to wages in the region around the median. We thus estimate a slight - but significant - U-shaped pattern along the distribution of wages. Considering changes in industry specific wages for medical and public services, we observe similar changes as

\footnotetext{
${ }^{40}$ In this study we use wage growth at the median to approximate the general wage trend within industries, see the discussion in section 3 .
} 
for women. However, these two sectors are much less important in size for male workers. Changes in observed sector-specific wage premia for these two industries contribute to the small gains estimated at the upper quantiles for men. In gender comparison, women lost relative to men below the $35 \%$ percentile, whereas wages evolved in favor of females above this point.

Summing up, our sequential decomposition analysis explains a major part of the observed increase in wage inequality by gender between 1992 and 2001. For female workers, the large increase of wage dispersion in the lower part of the distribution is partially explained by changes in individual characteristics. These compositional changes are likely to reflect some women opting out of the labor force or changing into part-time work, as well as migration to West Germany and skill-upgrading. However, the major part of rising wage inequality in the lower part of the distribution is contributed by changing industry specific premia. These changes reflect a tendency towards increasing wage flexibility across industries. A considerable share of women are concentrated in a few sectors exhibiting high collective bargaining coverage rates and paying relatively high wages. ${ }^{41}$ For these sectors wages increased uniformly across the distribution. The smaller increase of wage dispersion in the upper part of the distribution is explained by restructuring of the economy, as proxied by inter-industry shifts, and a general time trend. Inter-industry shifts alone would have caused wages for female workers to polarize.

For men, changes in individual characteristics, inter-industry shifts, and the residual time trend all contribute to the rise in wage inequality throughout the entire distribution. Changes in individual and industry coefficients add to the more pronounced increase of wage inequality in the upper part. Considering gender differences, it stands out that the sectoral transition as measured by the effects of industry characteristics and coefficients affected women to a much stronger degree than men. This key result is robust against inverting the order of our decomposition.

\section{Conclusions}

This paper examines the evolution of wage inequality in East Germany between 1992 and 2001. It therefore provides evidence on the observed increases in wage dispersion in transition economies. We analyze changes in the wage structure for males and females separately and study differences by gender. Wage inequality has generally been rising throughout the first decade after the German reunification: the 80-20 wage differential

\footnotetext{
${ }^{41}$ For instance, $90 \%$ of workers employed in the public service sector in East Germany in the year 1998 were covered by a collective wage bargaining agreement, while the consumer goods sector had coverage rates of less than 50\% (see e.g. Franz and Steiner, 2000).
} 
increased by $16 \log$ points for men and by even $29 \log$ points for women. The larger part of the increase in wage dispersion among female workers took place at the bottom of the distribution. In contrast, wage inequality among men increased to a larger part at the top. Estimating quantile regressions and applying decomposition techniques, we identify gender-specific driving forces behind this rise in wage inequality. These impacts differ substantially across the wage distribution.

Our results show that for female workers, the large increase of wage inequality in the lower part of the distribution is only partially explained by changes in individualspecific characteristics. Such changes capture the effect of less-skilled women dropping out of the labor force or changing into part-time, emigration or skill-upgrading. Earlier studies, which pointed out the importance of these changes considered mostly changes at the mean, and did in general not allow for heterogeneous effects along the distribution. We show that the larger share of the increase is due to changing sector-specific wage premia, suggesting increasing wage flexibility across industries. The (smaller) increase of wage dispersion in the upper part of women's distribution is mainly attributed to the restructuring of the economy, as proxied by inter-industry employment shifts. A general time trend, which would, e.g., take up the effects of the strong deunionization in East Germany in the 1990's also contributes to the increase of wage inequality in the upper part of the distribution.

Moreover, changes in the sectoral composition of the workforce caused women's wage structure to polarize - leading to increasing wage dispersion in the upper part of the distribution and decreasing inequality in the lower part. This polarization is mirrored by an employment shift away from the manufacturing towards the service sector. When the iron curtain fell and market forces were free to act at the beginning of the 1990's, the industry structure in countries of the Eastern bloc was heavily outdated. Thus, a restructuring process needed to take place, arguably so in fast motion compared to mature market economies. Changes in sector-specific remuneration schemes alone would actually have caused wage dispersion in the upper part of women's wage distribution to decline. This could indicate a catching-up process for jobs located in the middle of the wage distribution, which might, e.g., have been initiated by unions.

For men, changes in individual characteristics and the general time trend are the largest contributing factors to this rise throughout the entire distribution. While both shifts in industry characteristics and their corresponding coefficients exhibited a large impact on changes of the wage distribution of female workers, this sectoral transition has been far less important for males. An intuitive reason for this finding are gender differences in the industry composition of the workforce, and in particular the stronger concentration of female workers in the public service sector, right after German reunification. 


\section{References}

Antonczyk, D., DeLeire, T., and Fitzenberger, B. (2010a). Polarization and Rising Wage Inequality: Comparing the U.S. and Germany. IZA Discussion Paper, 4842.

Antonczyk, D., Fitzenberger, B., and Sommerfeld, K. (2010b). Rising Wage Inequality, the Decline of Collective Bargaining, and the Gender Wage Gap. Labour Economics, $17(5): 835-847$.

Antonczyk, D., Fitzenberger, F., and Leuschner, U. (2009). Can a Task-Based Approach Explain the Recent Changes in the German Wage Structure? Journal of Economics and Statistics, 229(2+3):214-238.

Arntz, M. (2010). What Attracts Human Capital? Understanding the Skill Composition of Interregional ob Matches in Germany. Regional Studies, 44(4):423-441.

Autor, D., Katz, L., and Kearney, M. (2008). Trends in U.S. Wage Inequality: ReAssessing the Revisionists. Review of Economics and Statistics, 90(3):300-323.

Autor, D. H., Katz, L. F., and Kearney, M. S. (2005). Rising Wage Inequality: The Role of Composition and Prices. Working Paper 11628, NBER.

Bender, S., Haas, A., and Klose, C. (2000). The IAB Employment Subsample 1975-1995. Schmollers Jahrbuch: Journal of Applied Social Science Studies, 120(4):649-662.

Bird, E. J., Schwarze, J., and Wagner, G. (1994). Wage Effects of the Move Toward Free Markets in East Germany. Industrial and Labor Relations Review, 47(3):390-400.

Blau, F. D. and Kahn, L. M. (1992). The Gender Earning Gap: Learning from International Comparisons. American Economic Review, 82(2, Papers and Proceedings):533538.

Blau, F. D. and Kahn, L. M. (1994). Rising Wage Inequality and the U.S. Gender Gap. American Economic Review, 84(2, Papers and Proceedings):23-28.

Blau, F. D. and Kahn, L. M. (1996). International differences in male wage inequality: Institutions versus market forces. Journal of Political Economy, 104(4):791-837.

Blau, F. D. and Kahn, L. M. (1997). Swimming Upstream: Trends in the Gender Wage Differential in the 1980s. Journal of Labor Economics, 15(1):1-42.

Blinder, A. S. (1973). Wage Discrimination: Reduced Form and Structural Estimates. Journal of Human Resources, 8(4):436-455.

Bonin, H. (2005). Tarifpolitik, Entgeltflexibilität und Beschäftigung in Ostdeutschland. Journal for Labour Market Research, 38(2/3):165-179.

Borghans, L., ter Weel, B., and Weinberg, B. A. (2006). People People: Social Capital and the Labor-Market Outcomes of Underrepresented Groups. Working Paper 11985, NBER. 
Brainerd, E. (2000). Women in Transition: Changes in Gender Wage Differentials in Eastern Europe and the Former Soviet Union. Industrial and Labor Relations Review, 54(1):138-162.

Brenke, K. (2001). Löhne in Ostdeutschland - Anpassung an das westdeutsche Niveau erst auf lange Sicht möglich. Wochenbericht des DIW Berlin, 68(24):357-364.

Burda, M. C., Fitzenberger, B., Lembcke, A., and Vogel, T. (2008). Unionization, Stochastic Dominance, and Compression of the Wage Distribution: Evidence from Germany. SFB 649 Discussion Paper 2008-041.

Burda, M. C. and Hunt, J. (2001). From Reunification to Economic Integration: Productivity and the Labor Market in Eastern Germany. Brookings Papers on Economic Activity, 2:1-92.

Burda, M. C. and Schmidt, C. M. (1997). Getting behind the East-West Wage Differential: Theory and Evidence. In Pohl, R. and Schneider, H., editors, Wandeln oder Weichen - Herausforderungen der wirtschaftlichen Integration für Deutschland, pages 170-201. IWH Halle. Sonderheft Wirtschaft im Wandel.

Chernozhukov, V., Fernández-Val, I., and Melly, B. (2008). Inference on counterfactual distributions. MIT Working Paper, 08-16.

DiNardo, J., Fortin, N. M., and Lemieux, T. (1996). Labor Market Institutions and the Distribution of Wages, 1973-1992: A Semiparametric Approach. Econometrica, 64(5):1001-1044.

Dustmann, C., Ludsteck, J., and Schönberg, U. (2009). Revisiting the German Wage Structure. The Quarterly Journal of Economics, 124(2):843-881.

Fitzenberger, B., Kohn, K., and Wang, Q. (2011). The Erosion of Union Membership in Germany: Determinants, Densities, Decompositions. Journal of Population Economics, 24(1):141-165.

Fitzenberger, B., Osikominu, A., and Völter, R. (2006). Imputation Rules to Improve the Education Variable in the IAB Employment Subsample. Schmollers Jahrbuch: Journal of Applied Social Science Studies, 126(3):405-436.

Franz, W. and Steiner, V. (2000). Wages in the East German Transition Process: Facts and Explanations. German Economic Review, 1(3):241-269.

Fuchs-Schündeln, N., Krueger, D., and Sommer, M. (2010). Inequality trends for Germany in the last two decades: A tale of two countries. Review of Economic Dynamics, 13:103132 .

Fuchs-Schündeln, N. and Schündeln, M. (2005). Precautionary Savings and Self-Selection: Evidence from the German Reuinification "Experiment". Quarterly Journal of Economics, 120(3):1085-1120.

Fuchs-Schündeln, N. and Schündeln, M. (2009). Who stays, who goes, who returns? East-West migration within Germany since reunification. Economics of Transition, 17(4):703-738. 
Gartner, H. (2005). The imputation of wages above the contribution limit with the German IAB employment sample. FDZ Methodenreport, 2.

Gernandt, J. und Pfeiffer, F. (2009). Wage convergence and inequality after unification: (East) Germany in transition. In und J. Svejna, R. K., editor, Labor Markets and Economic Development, pages 387-405. Routledge Studies in Development Economics Bd. 73, London.

Gernandt, J. and Pfeiffer, F. (2007). Rising Wage Inequality in Germany. Journal of Economics and Statistics, 227(4):358-380.

Goos, M. and Manning, A. (2007). Lousy and Lovely Jobs: The Rising Polarization of Work in Britain. Review of Economics and Statistics, 89:118-133.

Görzig, B., Gornig, M., and Werwatz, A. (2008). East Germanys Wage Gap: A nonparametric decomposition based on establishment characteristics. Economics of Transition, 16(2):273-292.

Hamann, S., Krug, G., Köhler, M., Ludwig-Mayerhofer, W., and Hacket, A. (2004). Die IAB-Regionalstichprobe 1975-2001: IABS-R01. ZA-Information, 55:34-59.

Hunt, J. (2001). Post-Unification Wage Growth in East Germany. Review of Economics and Statistics, 83(1):190-195.

Hunt, J. (2002). The Transition in East Germany: When Is a Ten-Point Fall in the Gender Wage Gap Bad News? Journal of Labor Economics, 20(1):148-169.

Hunt, J. (2006). Staunching Emigration from East Germany: Age and the Determinants of Migration. Journal of the European Economic Association, 4(5):1014-1037.

Juhn, C., Murphy, K. M., and Pierce, B. (1991). Accounting for the slowdone in blackwhite wage convergence. In Kosters, M. H., editor, Workers and their Wages, pages 107-143. AEI Press.

Juhn, C., Murphy, K. M., and Pierce, B. (1993). Wage Inequality and the Rise in Returns to Skill. Journal of Political Economy, 101(3):410-442.

Kirbach, M. and Smolny, W. (2004). Wage differentials between East and West Germany - Is it related to the location or to the people? unpublished manuscript, University of Ulm and ZEW Mannheim.

Kohn, K. (2006). Rising Wage Dispersion, After All! The German Wage Structure at the Turn of the Century. IZA Discussion Paper, 2098.

Kommission (1996). Erwerbstätigkeit und Arbeitslosigkeit in Deutschland - Entwicklung, Ursachen und Maßnahmen. Kommission für Zukunftsfragen der Freistaaten Bayern und Sachsen. http://www.bayern.de/imperia/md/content/stk/allgemein/bericht1.pdf, Oct. 1996.

Krueger, A. and Pischke, J.-S. (1995). A Comparative Analysis of East and West German Labor Markets: Before and After Unification. In Freeman, R. B. and Katz, L. F., editors, Differences and Changes in Wage Structures, pages 405-445. University of Chicago Press, Chicago, London. 
Machado, J. A. F. and Mata, J. (2005). Counterfactual Decomposition of Changes in Wage Distributions using Quantile Regression. Journal of Applied Econometrics, 20(4):445465.

Melly, B. (2005). Decomposition of differences in distribution using quantile regression. Labour Economics, 12(4):577-590.

Möller, J. (2005). Die Entwicklung der Lohnspreizung in West- und Ostdeutschland. In Bellmann, L., Hübler, O., Meyer, W., and Stephan, G., editors, Institutionen, Löhne und Beschäftigung, Beiträge zur Arbeitsmarkt- und Berufsforschung 294, pages 47-63. Institut für Arbeitsmarkt- und Berufsforschung, Nürnberg.

Oaxaca, R. (1973). Male-female wage differentials in urban labour markets. International Economic Review, 14(3):693-709.

Oaxaca, R. L. and Ransom, M. R. (1994). On discrimination and the decomposition of wage differentials. Journal of Econometrics, 61(1):5-21.

Oglobin, C. G. (1999). The Gender Earnings Differential in the Russian Transition Economy. Industrial and Labor Relations Review, 52(4):602-627.

Orlowski, R. and Riphahn, R. T. (2009). The East German wage structure after transition. Economics of Transition, 17:629-659.

Scheremet, W. (1995). Tarifpolitik in Ostdeutschland: Ausstieg aus dem Lohnverhandlungsmodell der Bundesrepublik Deutschland. Applied Economics Quarterly, 43:135169.

Schwarze, J. (1993). Qualifikation, Überqualifikation und Phasen des Transformationsprozesses - Die Entwicklung der Lohnstruktur in den neuen Bundesländern. Jahrbücher für Nationalökonomie und Statistik, 211:90-107.

Schwarze, J. and Wagner, G. (1992). Lohnstruktur und Lohnniveau in den neuen Bundesländern. Wirtschaftsdienst, pages 202-206. Heft IV.

Sinn, G. (1997). Lohnentwicklung und Lohnpolitk in den neuen Bundesländern. In Oppenländer, K. H., editor, Wiedervereinigung nach sechs Jahren: Erfolge, Defizite, Zukunftsperspektiven im Transformationsprozess, pages 249-280. Duncker \& Humblot, Berlin/München.

Spitz-Oener, A. (2006). Technical Change, Job Tasks, and Rising Educational Demands: Looking Outside the Wage Structure. Journal of Labor Economics, 24(2):235-270.

Steiner, V. and Wagner, K. (1997). East-West Wage Convergence - How Far Have We Got? Discussion Paper 97-25, ZEW Mannheim.

Steiner, V. and Wagner, K. (1998). Relative Earnings and the Demand for Unskilled Labor in West German Manufacturing. In Black, S. W., editor, Globalization, Technological Change, and Labor Markets, pages 89-111. Kluwer, Boston.

\section{Appendix}




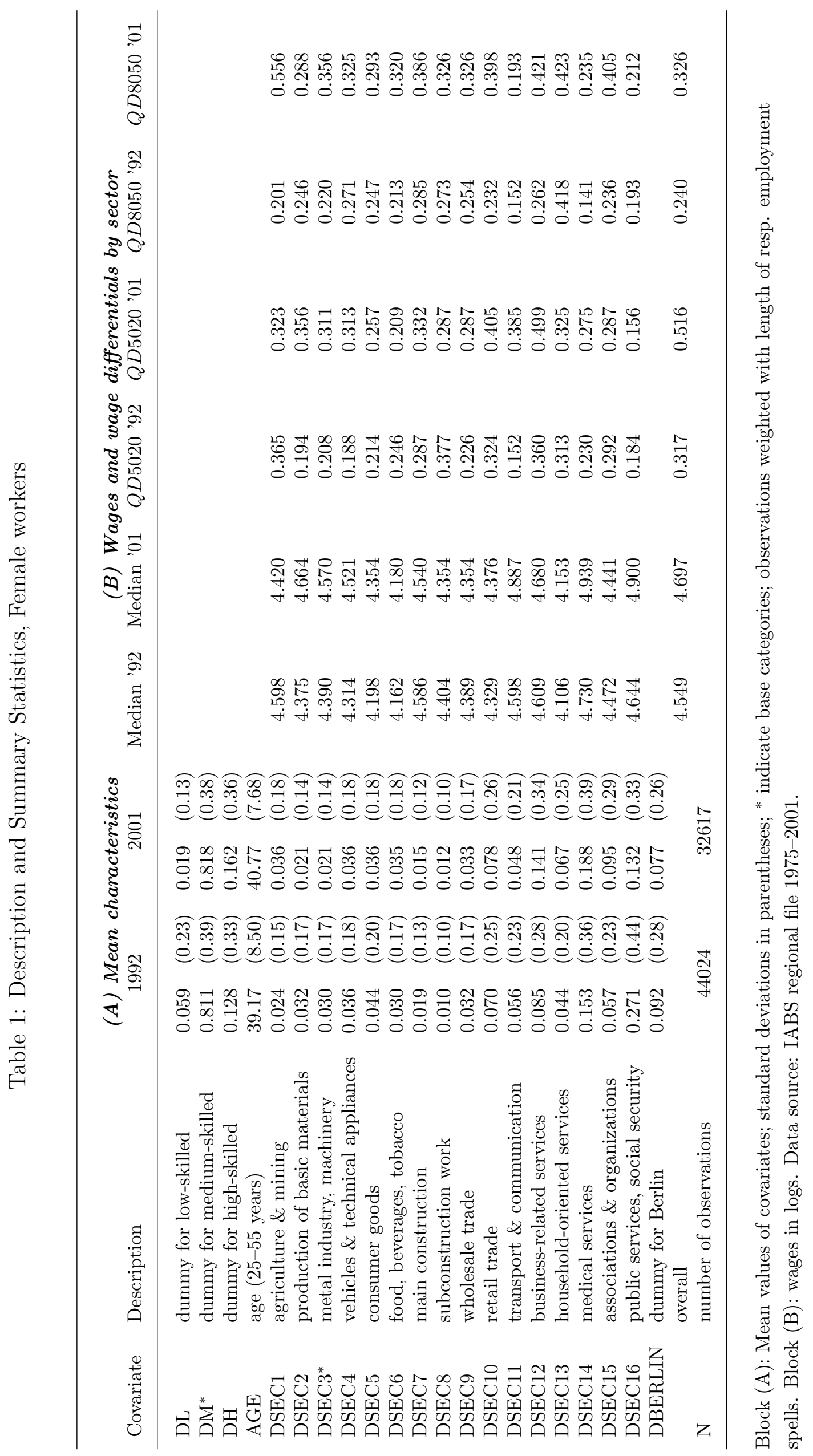




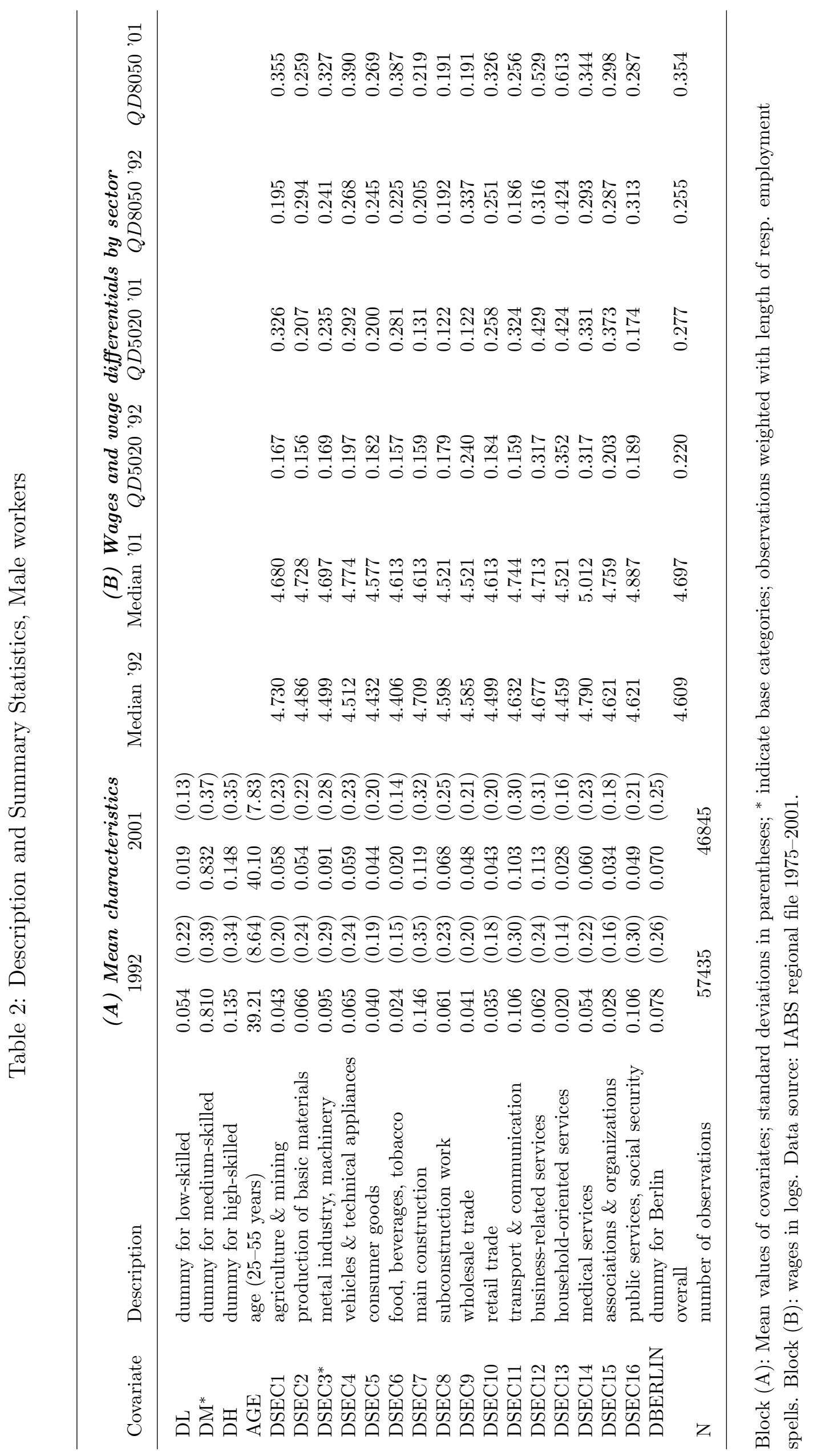


Table 3: Gender Wage Gap Across Wage Distributions

\begin{tabular}{lccccccccc}
\hline Percentile & 10th & 20th & 30th & 40th & 50 th & 60 th & 70th & 80th & 90th \\
\hline 1992 & 0.255 & 0.156 & 0.112 & 0.077 & 0.059 & 0.066 & 0.051 & 0.091 & 0.054 \\
2001 & 0.279 & 0.239 & 0.167 & 0.074 & 0.000 & -0.014 & -0.013 & 0.0342 & 0.084 \\
\hline
\end{tabular}

Log wage differences, evaluated at various percentiles. Data source: IABS regional file 1975-2001.

Table 4: Decomposition of Changes in Wage Differentials, Female Workers

\begin{tabular}{cccc}
\hline Differential & QD8020 & QD8050 & QD5020 \\
\hline Overall change & $0.286(0.010)$ & $0.086(0.009)$ & $0.199(0.011)$ \\
\hline Char. P & $0.034(0.009)$ & $-0.022(0.007)$ & $0.057(0.009)$ \\
Char. I & $0.071(0.008)$ & $0.068(0.005)$ & $0.003(0.006)$ \\
Coef. P & $0.004(0.007)$ & $0.003(0.003)$ & $0.001(0.005)$ \\
Coef. I & $0.103(0.004)$ & $-0.015(0.003)$ & $0.120(0.005)$ \\
Time trend & $0.072(0.003)$ & $0.056(0.002)$ & $0.016(0.001)$ \\
\hline
\end{tabular}

Changes 1992-2001. Standard errors in parentheses based on 200 bootstrap replications. Data source: IABS regional file 1975-2001. 
Table 5: Decomposition of Changes in Wage Differentials, Male Workers

\begin{tabular}{cccc}
\hline Differential & QD8020 & QD8050 & QD5020 \\
\hline Overall change & $0.156(0.006)$ & $0.099(0.008)$ & $0.057(0.008)$ \\
\hline Char. P & $0.050(0.006)$ & $0.023(0.008)$ & $0.027(0.006)$ \\
Char. I & $0.015(0.005)$ & $0.012(0.004)$ & $0.003(0.003)$ \\
Coef. P & $0.016(0.005)$ & $0.017(0.005)$ & $-0.001(0.005)$ \\
Coef. I & $-0.002(0.003)$ & $0.016(0.002)$ & $-0.018(0.002)$ \\
Time trend & $0.077(0.004)$ & $0.031(0.002)$ & $0.046(0.002)$ \\
\hline
\end{tabular}

Changes 1992-2001. Standard errors in parentheses based on 200 bootstrap replications. Data source: IABS regional file $1975-2001$. 
Figure 1: Density Estimates of Log Real Wages

Females 1992

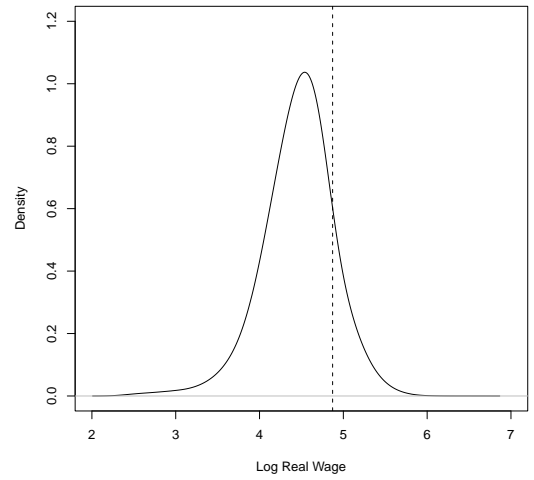

Males 1992

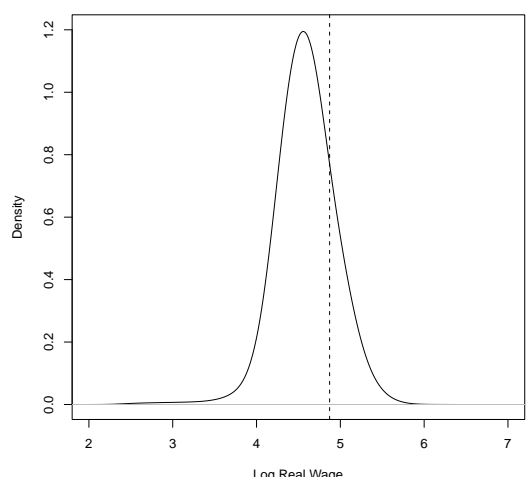

Females 2001

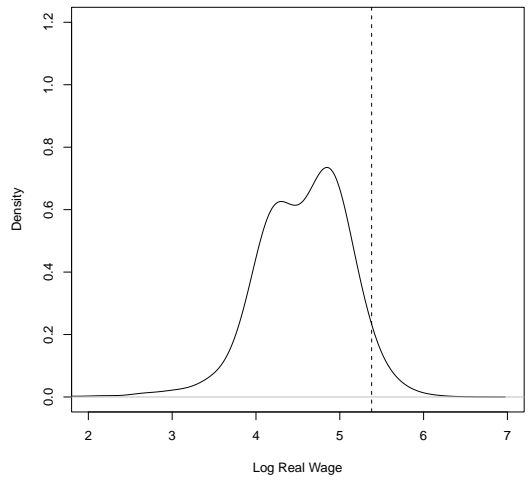

Males 2001

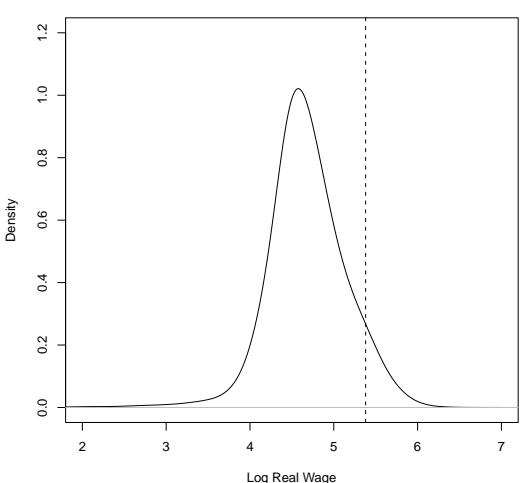

Dashed lines indicate the social security threshold, above which wages are imputed. Data source: IABS regional file 1975-2001. 
Figure 2: Unconditional Cumulated Real Wage Growth 1992-2001, Evaluated at 20\%, $50 \%$, and $80 \%$ Quantiles

Females

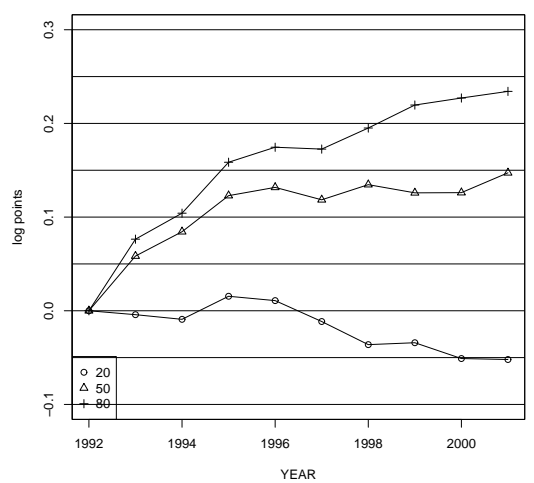

Males

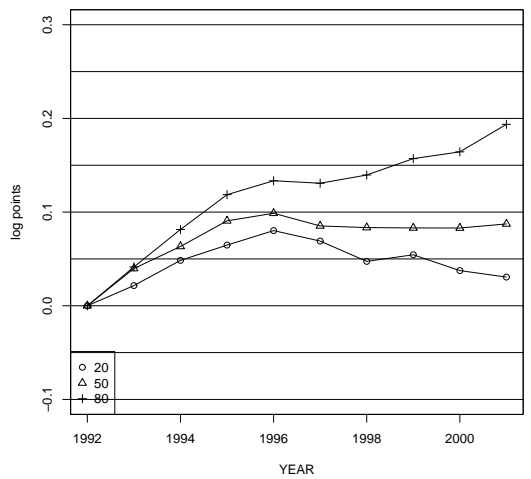

Data source: IABS regional file 1975-2001.

Figure 3: Relative Employment Changes across Industries, Female Workers

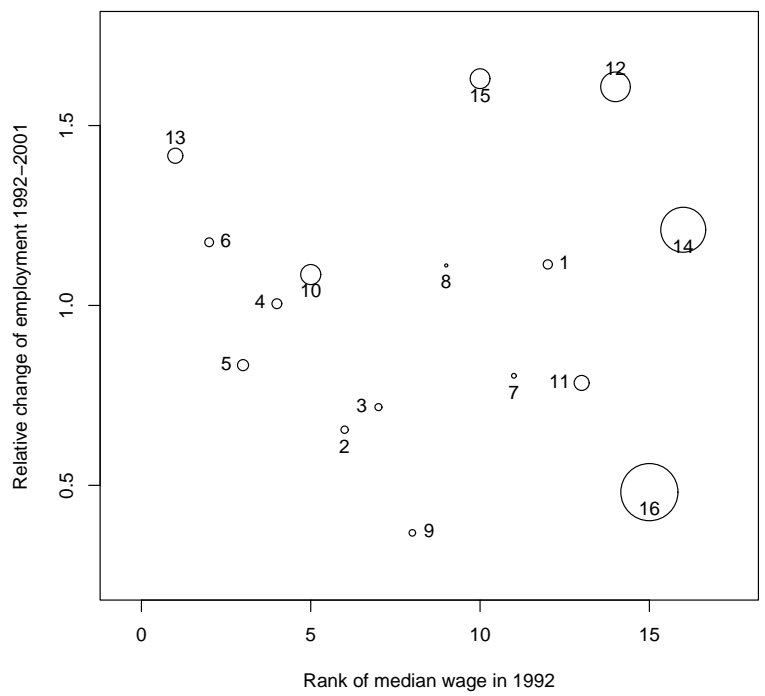

Numbers indicate industries as defined in tables 1 and 2. The size of the circles indicates the relative importance of the sectors, measured as the the sum of the number of employment spells over both years. Data source: IABS regional file 1975-2001. 
Figure 4: Relative Employment Change across Industries, Male Workers

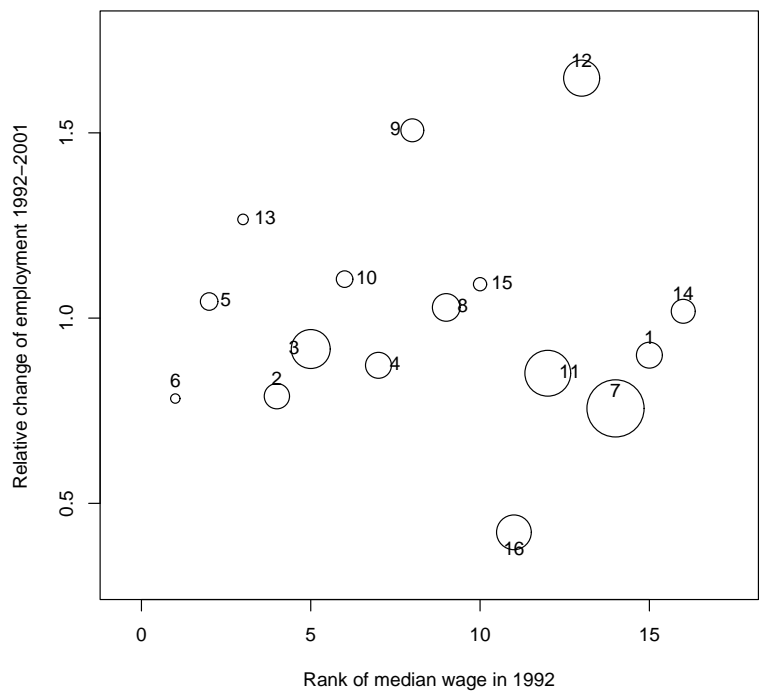

Numbers indicate industries as defined in tables 1 and 2. The size of the circles indicates the relative importance of the sectors, measured as the the sum of the number of employment spells over both years. Data source: IABS regional file $1975-2001$.

Figure 5: Machado-Mata Decomposition of Wage Changes 1992-2001, by Gender

Females

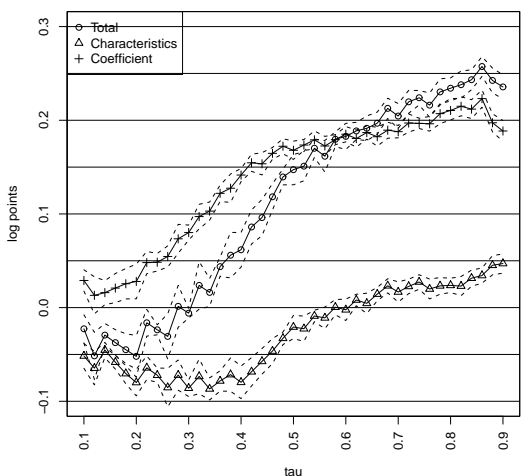

Males

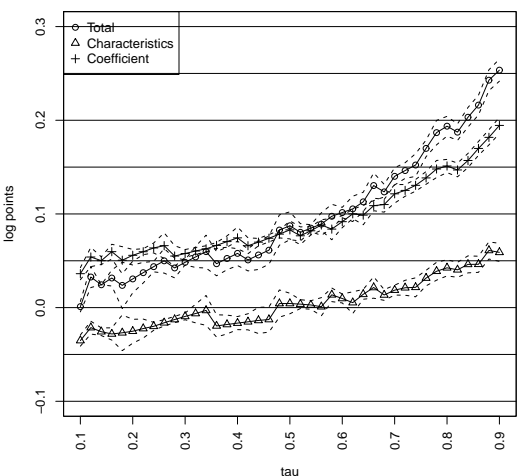

Dashed lines: confidence bands based on 200 bootstrap replications. Data source: IABS regional file 1975-2001. 
Figure 6: Sequential Decomposition of Changes in the Female Wage Distribution

Total

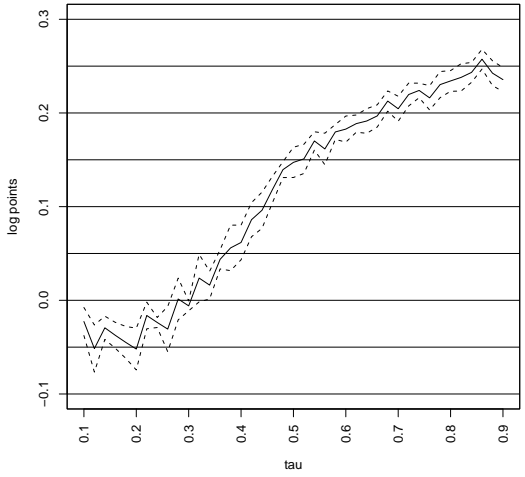

Industry Characteristics

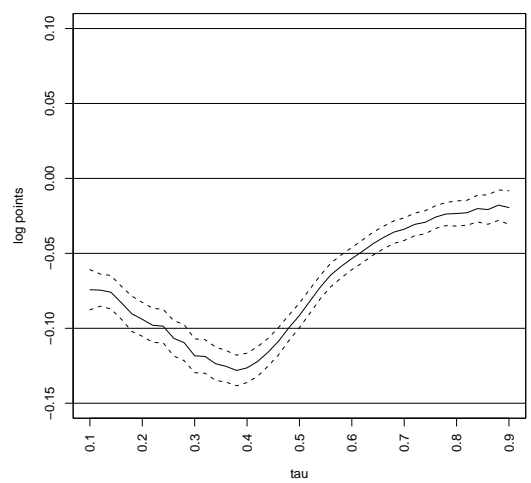

Industry Coefficients

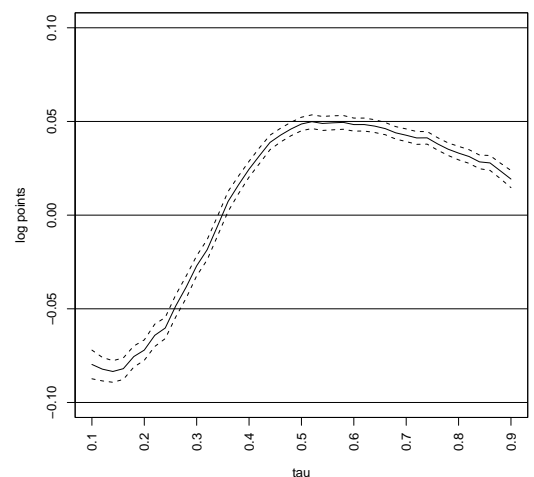

Individual Characteristics

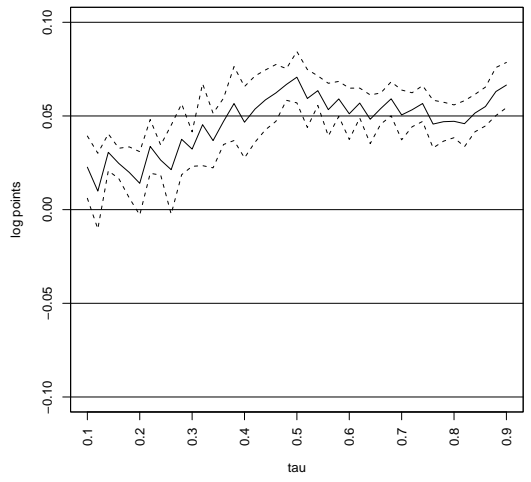

Residual

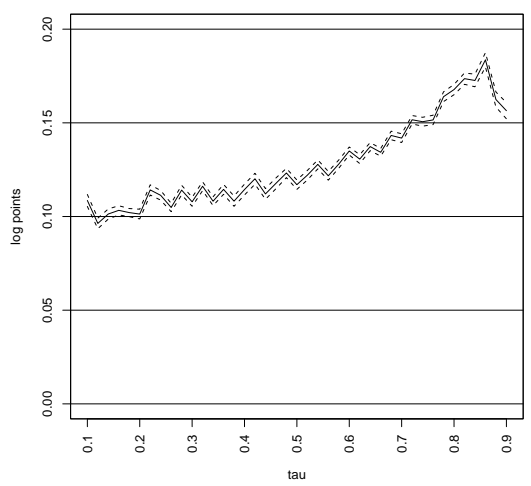

Individual Coefficients

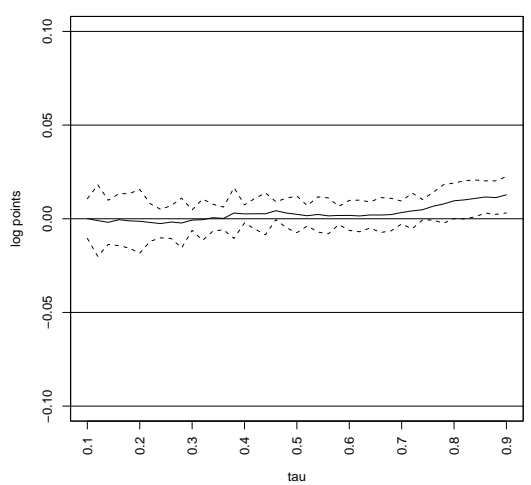

Changes 1992-2001. Dashed lines: confidence bands based on 200 bootstrap replications. Data source: IABS regional file $1975-2001$. 
Figure 7: Sequential Decomposition of Changes in the Male Wage Distribution

Total

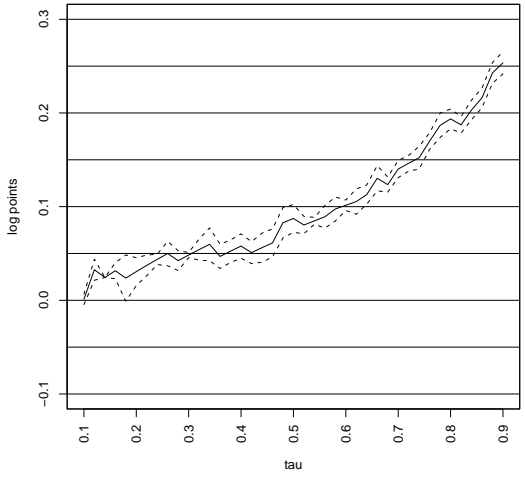

Industry Characteristics

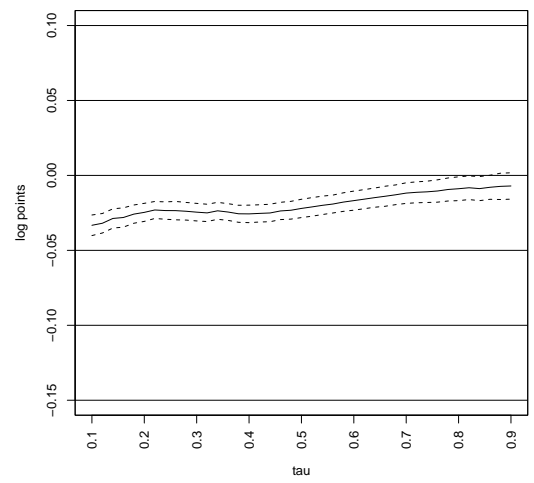

Industry Coefficients

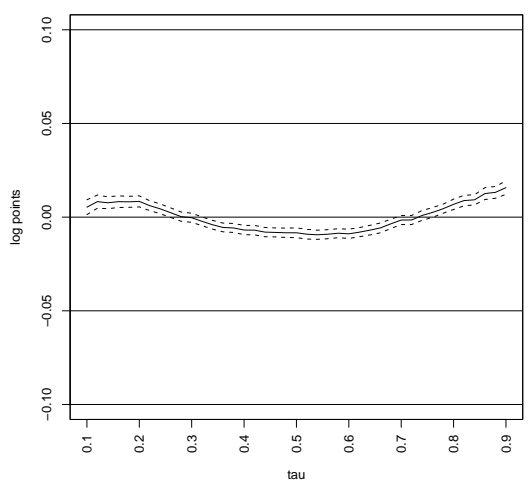

Individual Characteristics

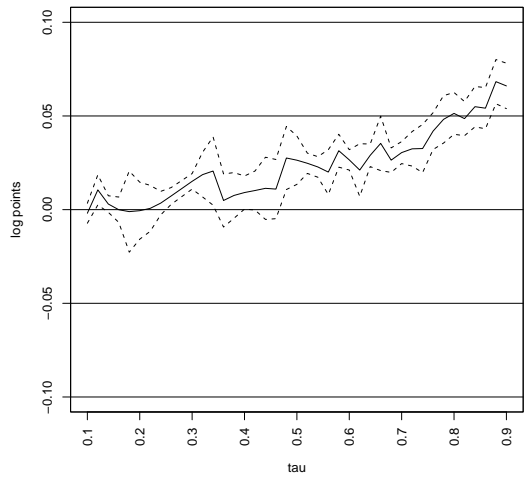

Residual

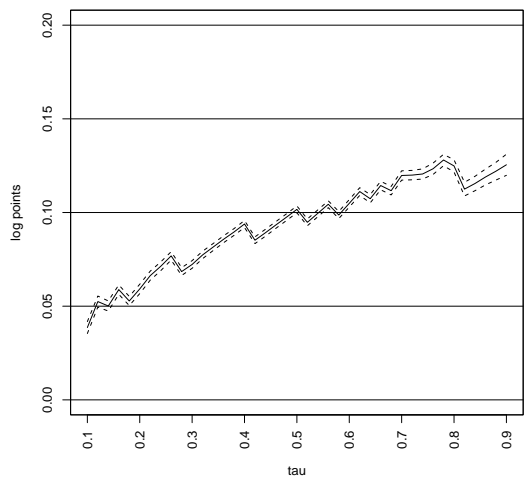

Individual Coefficients

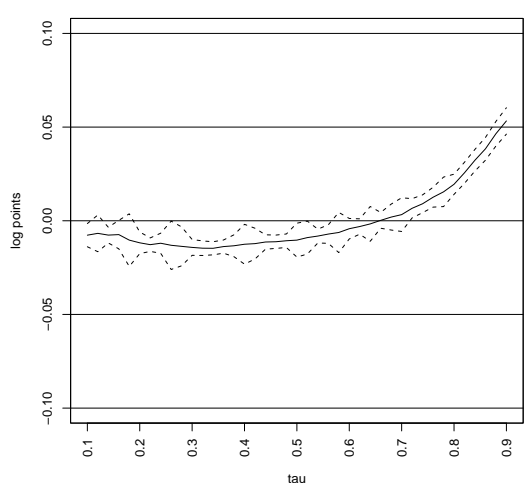

Changes 1992-2001. Dashed lines: confidence bands based on 200 bootstrap replications. Data source: IABS regional file 1975-2001. 


\section{Robustness Check: Alternative Decomposition Sequence}

The results of any decomposition analysis depends upon the chosen order of sequence. As a robustness check to our preferred sequence motivated in section 4, we also implement an alternative order of decomposition. Here we start with changing the coefficients and end with changing the characteristics, i.e., we now take the perspective of individuals from the year 2001. The alternative sequence reads as follows:

$$
\begin{aligned}
& \Delta_{\tau}^{1}=q_{\tau}^{01}\left(\alpha_{P}^{01}, \alpha_{F}^{01}, \bar{\alpha}_{0}^{01}, F^{01}, P^{01}\right)-q_{\tau}^{01}\left(\alpha_{P}^{01}, \alpha_{F}^{01}, \bar{\alpha}_{\mathbf{0}}^{\mathbf{9 2}}, F^{01}, P^{01}\right) \\
& \Delta_{\tau}^{2}=q_{\tau}^{01}\left(\alpha_{P}^{01}, \alpha_{F}^{01}, \bar{\alpha}_{0}^{92}, F^{01}, P^{01}\right)-q_{\tau}^{01}\left(\alpha_{P}^{01}, \alpha_{\mathbf{F}}^{\mathbf{9 2}}, \bar{\alpha}_{0}^{92}, F^{01}, P^{01}\right) \\
& \Delta_{\tau}^{3}=q_{\tau}^{01}\left(\alpha_{P}^{01}, \alpha_{F}^{92}, \bar{\alpha}_{0}^{92}, F^{01}, P^{01}\right)-q_{\tau}^{01}\left(\alpha_{\mathbf{P}}^{\mathbf{9 2}}, \alpha_{F}^{92}, \bar{\alpha}_{0}^{92}, F^{01}, P^{01}\right) \\
& \Delta_{\tau}^{4}=q_{\tau}^{01}\left(\alpha_{P}^{92}, \alpha_{F}^{92}, \bar{\alpha}_{0}^{92}, F^{01}, P^{01}\right)-q_{\tau}^{01}\left(\alpha_{P}^{92}, \alpha_{F}^{92}, \bar{\alpha}_{0}^{92}, \mathbf{F}^{\mathbf{9 2}}, P^{01}\right) \\
& \Delta_{\tau}^{5}=q_{\tau}^{01}\left(\alpha_{P}^{92}, \alpha_{F}^{92}, \bar{\alpha}_{0}^{92}, F^{92}, P^{01}\right)-q_{\tau}^{92}\left(\alpha_{P}^{92}, \alpha_{F}^{92}, \bar{\alpha}_{0}^{92}, F^{92}, \mathbf{P}^{\mathbf{9 2}}\right)
\end{aligned}
$$

Figures 8 and 9 graphically summarize the corresponding results. Note that the results do not change qualitatively for most effects, except that now individual characteristics only seem to play a smaller role for explaining changes of the wage structure. In addition, inter-industry shifts are somewhat less important in magnitude. Both coefficients effects for individual characteristics and industry characteristics are robust to the alternative order, and so is the result that inter-industry shifts have a more heterogeneous impact on female workers than on male workers. 
Figure 8: Sequential Decomposition of Changes in the Female Wage Distribution, Alternative Decomposition Order

Total

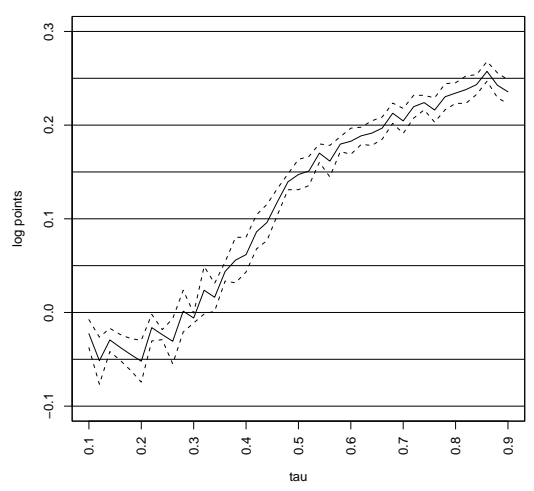

Industry Characteristics

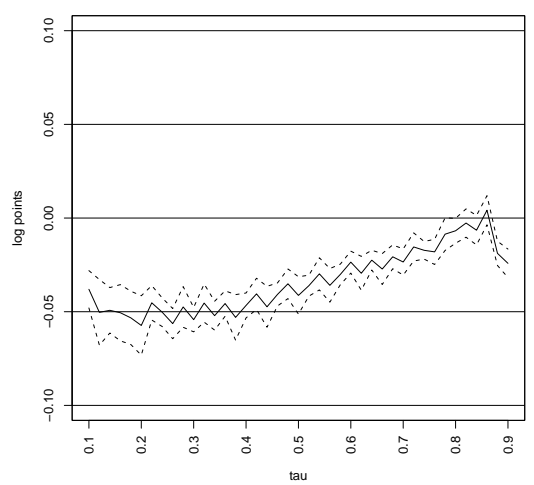

Industry Coefficients

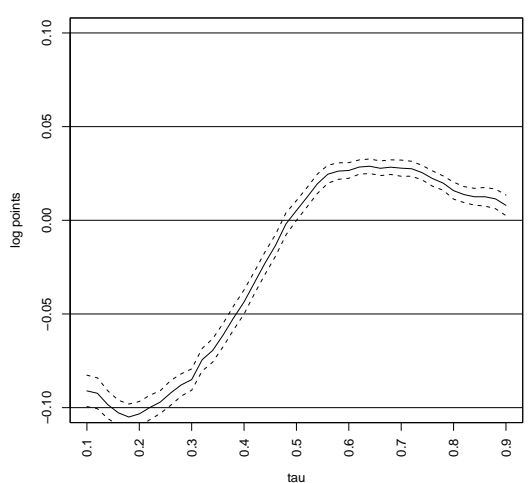

Individual Characteristics

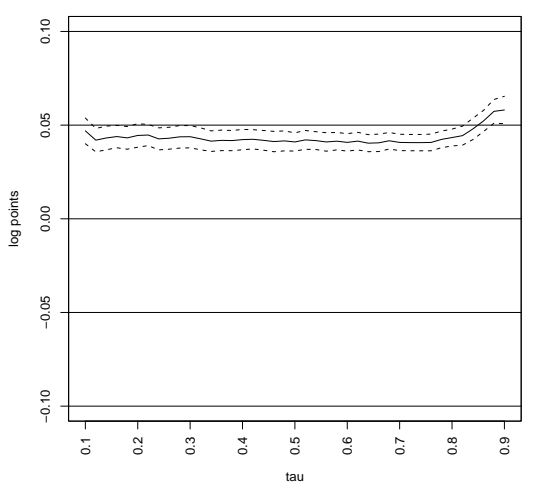

Residual

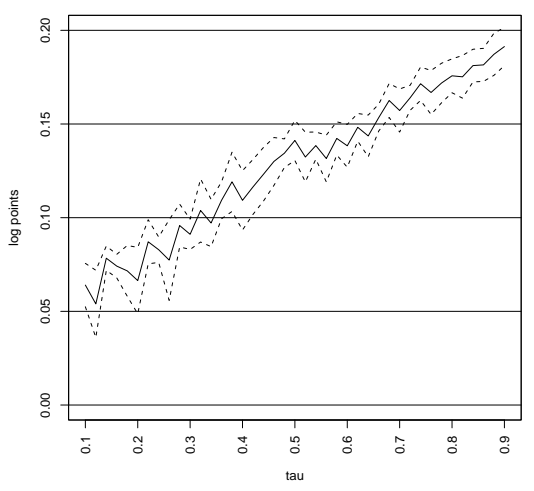

Individual Coefficients

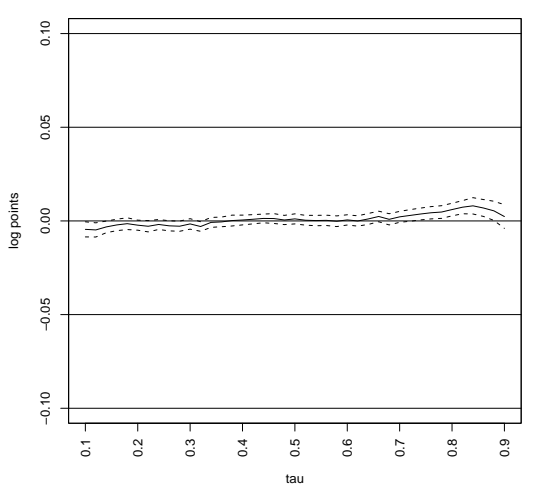

Changes 1992-2001. Dashed lines: confidence bands based on 200 bootstrap replications. Data source: IABS regional file 1975-2001. 
Figure 9: Sequential Decomposition of Changes in the Male Wage Distribution, Alternative Decomposition Order

Total

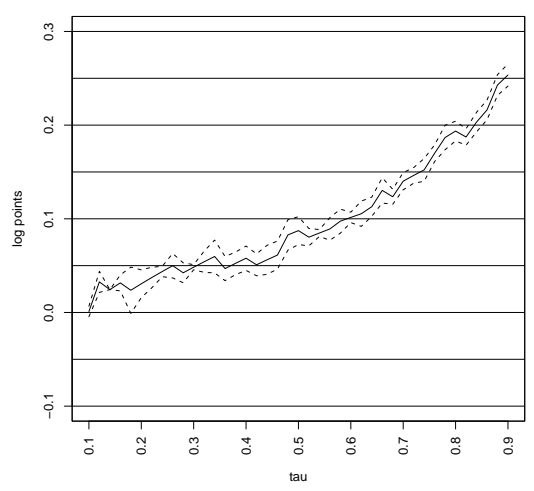

Industry Characteristics

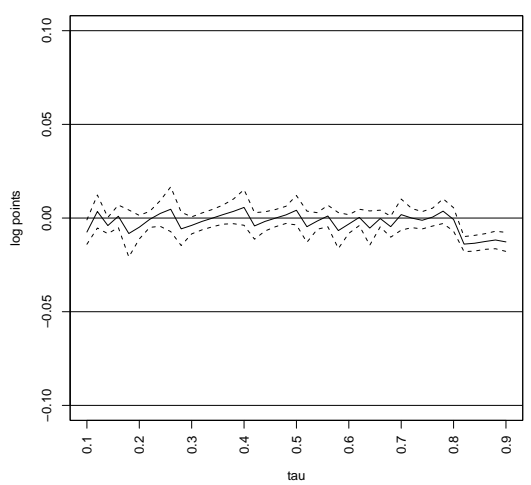

Industry Coefficients

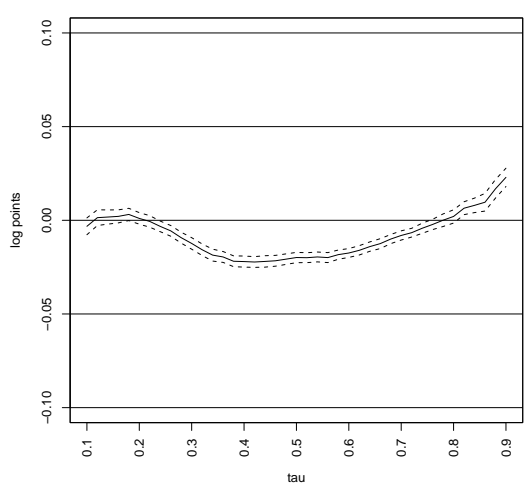

Individual Characteristics

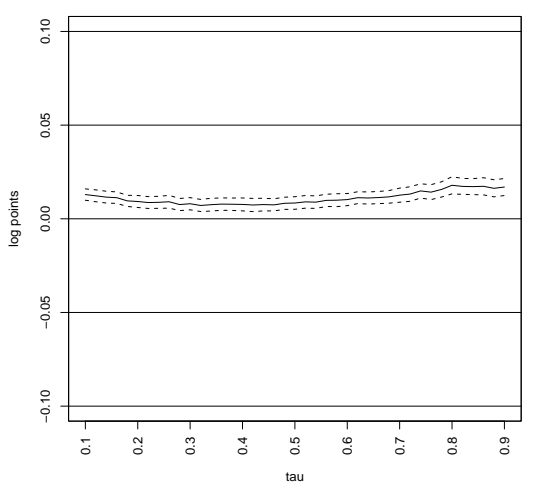

Residual

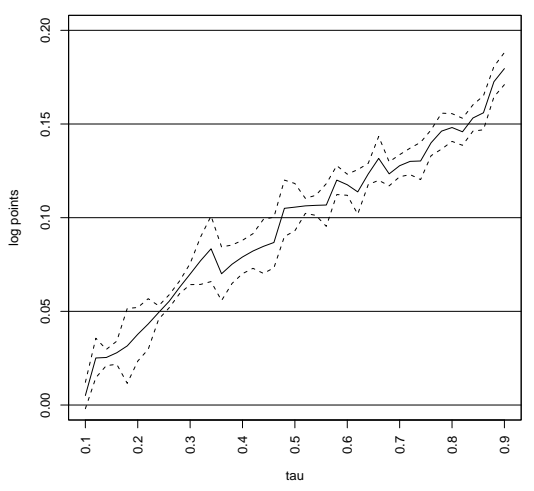

Individual Coefficients

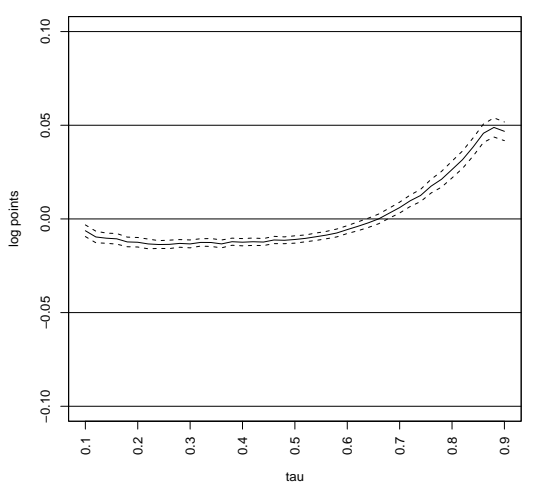

Changes 1992-2001. Dashed lines: confidence bands based on 200 bootstrap replications. Data source: IABS regional file 1975-2001. 